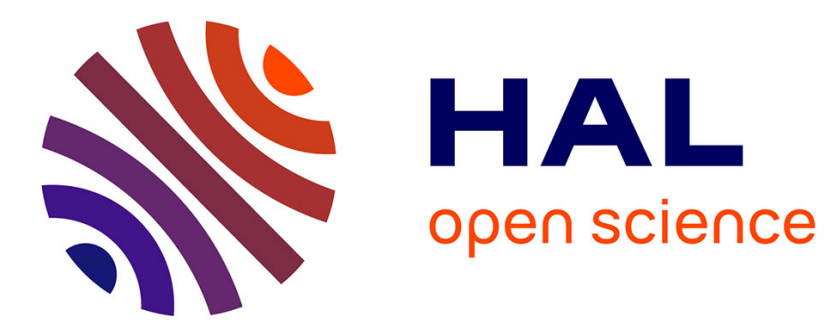

\title{
The difficult relationship between the consultancy market and SMEs: inspiring insights from the case of Drôme
}

\author{
Elisa Salvador, Hassan El Asraoui, Mylene Akbaraly
}

\section{- To cite this version:}

Elisa Salvador, Hassan El Asraoui, Mylene Akbaraly. The difficult relationship between the consultancy market and SMEs: inspiring insights from the case of Drôme. Revue de l'Entrepreneuriat, 2019, 18 (4). hal-02513526

\author{
HAL Id: hal-02513526 \\ https://hal.science/hal-02513526
}

Submitted on 20 Mar 2020

HAL is a multi-disciplinary open access archive for the deposit and dissemination of scientific research documents, whether they are published or not. The documents may come from teaching and research institutions in France or abroad, or from public or private research centers.
L'archive ouverte pluridisciplinaire HAL, est destinée au dépôt et à la diffusion de documents scientifiques de niveau recherche, publiés ou non, émanant des établissements d'enseignement et de recherche français ou étrangers, des laboratoires publics ou privés. 


\title{
This article has been accepted for publication by the Journal Revue de l'Entrepreneuriat
}

\author{
It can be cited as follows: \\ Salvador E., El Asraoui H., Akbaraly M. (2019), "The difficult relationship \\ between the consultancy market and SMEs: inspiring insights from the case of \\ Drôme", Revue de l'Entrepreneuriat, vol. 18, n. 4, pp. 127-157.
}

\author{
"The difficult relationship between the consultancy market and SMEs: \\ inspiring insights from the case of Drôme"
}

\author{
Salvador Elisa*, El Asraoui Hassan**, Akbaraly Mylene***
}

\begin{abstract}
:
Small and medium-sized enterprises (SMEs) play an important role in the economy, but their specific status brings several difficulties that large firms do not have to face. Among others, the literature underlines a market gap in SME consultancy services, with a weak demand from SME managers. The aim of this article is to understand actual SMEs" "practices and perceptions" of the consultancy market and thus to provide some recommendations about how external consultants could adapt their services to foster, meet, and maintain the demand of SMEs. The research focuses on actors located in the department of Drôme, France. Descriptive statistics from a questionnaire and a cluster analysis highlight the role played by a long-lasting relationship and a specialisation in the sector of activity of the SME. Trust, experience and expertise seem to be the keywords. Consultants have to be able to provide unique and creative solutions that are strictly linked to the consultants' commitment of gaining SMEs' trust and building strong ties and networking in order to overcome the distrust and autonomy propensity of SMEs.
\end{abstract}

Keywords: SMEs, consultancy market, trust, questionnaire, cluster analysis

* PhD, HDR, Professor ESSCA School of Management, Paris, France, corresponding author, e-mail: Elisa.SALVADOR@essca.fr, phone +33141862001

**, *** IÉSEG School of Management, Paris and Lille, France

This article has benefitted from the empirical contributions of Akbaraly Mylene during the research work for her master thesis ("Consultancy services dedicated to small and medium-sized enterprises: A survey of companies located in the department of Drôme", Iéseg School of Management, December 2015) directed and supervised by Prof. Elisa Salvador.

A preliminary but significantly different version of this paper (under the title "The difficult relationship between the consultancy market and SMEs: inspiring insights for future improvements") was presented at the XXVIe Conférence Internationale de Management Stratégique (AIMS), 7-9 June 2017, Manufacture des Tabacs, iaelyon-Université Jean Moulin, Lyon.

About the authors

Elisa SALVADOR holds a higher doctorate (Habilitation à Diriger des Recherches, HDR) in economics sciences and management conferred from Paris13 University (October 2019) and an international PhD in Institutions, Economics and Law from the University of Turin, Italy. She has worked for the Italian National Research Council (CNR) on several projects focused on innovation policies. She won the CNR award "Promotion of Research 2005" for her project "The financing of research spin-offs: An analysis of the Italian case". She has recently collaborated with the Polytechnic of Turin and with the ESCP-Europe 
Business School and she has been adjunct Professor at Iéseg School of Management, Economics and International Business Economics tracks (2014-2016). She has been a researcher at Ecole Polytechnique, Paris (2012-2015) working in particular on a project focused on R\&D and innovation in cultural and creative industries. She is currently permanent professor at ESSCA School of Management, Management and Corporate Environment Department, where she is the coordinator of the Master 1 course "Managing Creativity and Innovation".

Hassan EL ASRAOUI holds a PhD in Economics. He is associate professor at Iéseg - School of Management and Track Coordinator of "International Business \& Economics” Master Grande École.

Mylene AKBARALY holds a Master in Economics from Iéseg School of Management. 
Introduction

Representing the majority of companies in Europe (European Commission, 2014), small and medium-sized enterprises (SMEs) are particularly recognised as important actors in regard to job and wealth creation (Daly \& McCann, 1992; Floyd \& McManus, 2005; Lauder et al., 1994; O'Regan \& Ghobadian, 2004; Salvador et al., 2013; 2014).

Notwithstanding, SMEs usually have limited resources, which could influence their growth and development (Julien \& Manchesnay, 1988; Kim et al., 2015; Nicolescu, 2009; North et al., 2001). Pullen et al. (2008: 2) argued that "SMEs need to focus on core competencies for efficiency matters, and they need to cooperate with external partners to compensate for other competences and resources". To overcome this lack of resources and, thus, ensure their survival and growth, a solution may be represented by external support providers (Carey, 2015; Carey \& Tanewski, 2016; Jay \& Schaper, 2003; Kent, 1994). External consultants could help the SME develop strategies for growth or organizational change and strategic renewal as well as employ new management ideas: in short, they could play a key role in introducing managerial innovations (Damanpour \& Schneider, 2009; Damanpour \& Aravind, 2012; Wright et al., 2012). The consultancy market, through the work for one client, could even contribute to the development of new organizational forms or management systems successively implemented in several other companies ${ }^{1}$.

External support refers to all kinds of services provided by actors outside the concerned company (Srinivasan, 2014). It may essentially consist of helping the company in a defined area by offering knowledge, experience, and competences which the company cannot access through its internal resources. Generally speaking, "smart outsiders" aim to help to solve a problem that the company is facing or to improve its management competencies or strategy through their consulting activities (Christensen et al., 2013). The final purpose is to develop and enhance the company's activities and performance. The impact of consultancy has been both understated and overstated in the literature and this activity has been regarded as fascinating on the one hand as well as ambiguous and uncertain on the other hand (Sturdy, 2011).

External support can be provided at different levels, according to the type of entity providers: from simple knowledge transfer to direct implementation in the company system. The type of support providers is also important as they are varied (Bennett \& Robson, 1999; Ramsden \& Bennett, 2005). The literature (Bennett \& Robson, 1999; Berry et al., 2006) identifies, among others, consulting agencies, trainers, government agencies, and professional specialists. Otherwise, Soriano et al. (2002) suggest that the advisors should, in all cases, train the owner-managers when offering their services ${ }^{2}$.

Nonetheless, Glodek et al. (2016) have recently underlined that the contribution of business advice to the development process of SMEs is still poorly understood. Following the "need to re-think and re-evaluate the image and role of management consultancy more generally" highlighted by Sturdy et al. (2009: 645), the aim of this article is to understand the actual SMEs' "practices and perceptions" (Sturdy, 1997) of the consultancy market and, consequently, to advance useful recommendations for improving the weak demand from this particular kind of company. We will consider external support providers as all the public or private actors able to deliver knowledge which is not available at an internal level in a firm and which is offered as a commercial service (Curran, 2000; Gibb, 2000).

A questionnaire investigation was undertaken between September and October 2015 in companies located in the Drôme area in France. The Drôme department can be considered a representative example: this area is part of the Rhône-Alpes region, which benefits from

\footnotetext{
${ }^{1}$ The role of consultants in the diffusion of managerial innovations has been particularly investigated by Mol and Birkinshaw (2014).

${ }^{2}$ Soriano et al. (2002: 100) state that "the aim of the advisor is not only to draw up a plan but also to set up a relationship based on mutual collaboration so that the client (owner-managers) learns how to resolve his or her problems in the future".
} 
governmental support services (such as "plan PME"1). Drôme is, therefore, a well representative example of the French national market of SMEs (INSEE, 2013). Last but not least, Sturdy (2011) highlighted the wide quantity of studies on consultancy at a general level but scarce knowledge about detailed practices and activities. In line with this reasoning, we contribute to the existing literature through a detailed and specific case-study analysis focused on the French Drôme area.

The main findings from our analysis underline the pivotal role played by a long-lasting relationship and a specialisation in the sector of activity of the SME. Trust, experience and expertise seem to be the keywords. Consultants have to be able to provide original and creative solutions that are strictly linked to the consultants' commitment of gaining SMEs' trust and building strong ties and networking (Granovetter, 1973; Coleman, 1988; Morgan, Hunt, 1994) in order to overcome the distrust (Connelly et al., 2012) and autonomy propensity of SMEs.

The article is structured as follows: Section 1 provides an overview about the positive and negative image of consultancy in the academic literature. Section 2 provides some insight into the main specificities of SMEs and the reasons for the weak demand for consulting services while Section 3 underlines the key role played by trust and social networks. Section 4 describes the methodology adopted, while Section 5 presents some descriptive statistics from the questionnaires received. Section 6 underlines the cluster analysis findings. Finally, Section 7 provides a discussion and some concluding remarks.

\section{Consultancy in the academic literature: appreciations and criticism}

The world of consulting is ancient and it has for long been characterized by stability and immutability: its fundamental business model was focused on "opacity and agility" and it did not change for many years because what consultants did used to work well (Christensen et al., 2013) and there was a sort of fascination around consultancy activities (Sturdy, 2011). Fincham et al. (2008) highlighted the image of "expert outsiders", marginal but powerful figures, playing a role of intermediaries usually seen as "sector specialists". Wright et al. (2012) underlined the significant role of consultants in management innovation using standardized practices. In general, research about management consulting was characterized by a first phase of "organization development" looking at the effectiveness of consulting activities, and a second phase of "critical assessment" about the nature of knowledge held by consultants (Fincham, Clark, 2002, 2003; Hicks et al., 2009). Even if there is no consensus about what constitutes effectively management consultancy, consulting activities are in essence a knowledge-intensive business characterized by an intangible nature and a consequent uncertainty (Sturdy et al., 2013; Baaij, 2014).

According to Mosley (1970), management consulting reached maturity in the 1960s: external experts started to be solicited more and more for providing recommendations and helping solve critical problems or take decisions about the future strategy of the company. During the 1980s and the 1990s this industry assisted to an exceptional growth in many advanced economies (Fincham, Clark, 2003). Facing this increasing popularity of consulting practices, yet in 1970 Mosley alerted about the problem of unethical and incompetent practices in the field. Along this line of reasoning, recently Rival and Major (2018) even focused on ethical practices adopted by lobbying consulting profession in France, a country dominated by networks. And Sturdy (2011: 517) argued "for a more cautious and critical approach. This recognizes consultancy as an integral part of management, where its distinctive role lies more in

\footnotetext{
${ }^{1}$ The "Plan PME" is a service available to SMEs, with the aim of "offering the opportunity to be accompanied by experts in order to strengthen their performance, stimulate job creation and foster growth". The SME plan is a policy action offered and financed by both the national and the European governments and by the territorial authorities of the region. (Official website of the SME plan, available at : http://planpme.rhonealpes.fr)
} 
its structural position and ambiguous visibility and accountability than its practices, skills or occupational/professional identity claims".

Lory and McCalman (2002) underlined the need to establish a "brand" in order to gain a legitimizing status: they highlighted the pivotal role played by the consultant, meaning the person that provides the consultancy activity. As the range of activities proposed is essentially the same, the real difference comes from reputation linked to quality of the service, experience and capability offering. To this aim, Lory and McCalman (2002) argued that intangible components of brands, like client relationships, are of key importance. Sturdy et al. (2013) even argued that a good relationship with clients and credibility building may be seen as necessary conditions for survival and success. As a matter of fact, clients have difficulties in judging consultancy's performance in advance because they lack the knowledge and capability held by the external experts who have been recruited exactly for their smart capacities. This explains the pivotal role played by brand, reputation and social proof that replace an ex post verification of results (Christensen et al., 2013). Furthermore, this reveals the importance of knowledge components, difficult to identify and evaluate. To this aim, Hicks et al. (2009) remind that critiques ${ }^{1}$ have been advanced by some management scholars that considered consulting knowledge as "a rhetorical construction" benefiting from the influent power of consultants (Fincham, Clark, 2002). Furthermore, Hicks et al. (2009) argued that knowledge transfer from external consultants to clients reveals usually poor results. The knowledge and expertise that consultants bring into the company led to define consultants themselves as the "shock troops" of the new age, the "key agents and symbols of contemporary social change", the "capitalism's commissars", the "promoters of new management fashions", "pre-eminent knowledge brokers" or knowledge mediators, "corporate puppets", under a positive or negative association (O'Shea, Madigan, 1998; Fincham, Clark, 2003; Thrift, 2005; McKenna, 2006; Sturdy et al., 2009; Sturdy, 2011). Consultants may respond to the anxiety of clients through providing knowledge and new management fads that sometimes could reveal to be persuasive and confident but also ambiguous and rhetorical (Sturdy, 1997; Baaij, 2014). Sturdy (2009: 459) underlined the "constant questioning of the cost and value of consulting use": consultant activities are sometimes perceived as expensive and ineffective and as a waste of valuable resources because of lack of novelty or substance of the underlining ideas (Fincham, Clark, 2003). Finally, ethical and sensitivity concerns are also raised: self-interest, arrogance and lack of sense of responsibility are sometimes reproved to consultants (Sturdy, 2009).

Christensen et al. (2013) argued that disruption was starting to reshape also the consulting industry because of the arrival of sophisticated competitors using new business models. More specifically, "integrated solution shops" could be replaced by "modular providers", meaning experts in one specific element of the value chain. This shift could comply with the clients' needs of lower costs as well as more speed, responsiveness and control.

\section{SMEs and external consultants: Why is the demand weak?}

SMEs have attracted an increasing interest in the academic literature over the last decades: the positive and negative consequences of their smallness started to be investigated indepth. In particular, a higher need for support is supposed and focus is given to the role played by the entrepreneur leading the company. A strong link between the demand for support, the entrepreneur's perception about it and SMEs' attitude to independence is expected. Furthermore, knowledge about the sector and industry specialization is also highlighted as a pivotal aspect. The specificity paradigm of SMEs is underlined as well as the importance played by trust (cf. Section 3). All these elements partly explain the difficulties in investigating the world of SMEs, the consequent lack of data and reliable theories and therefore a weak demand for external support.

\footnotetext{
${ }^{1}$ For a detailed review of the most popular critiques of consultancy, see, among others, Fincham, Clark (2003), Sturdy (2009) and Sturdy (2011).
} 
The academic literature has focused specifically on entrepreneurship and SMEs since the 1980s (Gibb, 2000; Marchesnay, 2003). Julien (1994) highlighted this trend of focusing more on SMEs than on large firms with the creation of several scientific journals specialised in SMEs. ${ }^{1}$ Before this period, SMEs were described like a small version of larger firms (Torrès, 1997). Even if Penrose (1959) raised the important differences in the management of very large enterprises as opposed to very small ones, it is only at the end of the 1970s that SMEs came to be considered in the literature as a specific entity (cf. among others Gervais, 1978; Dandridge, 1979; Welsh \& White, 1981).

The most underlined characteristics of SMEs ${ }^{2}$ are all linked to the "smallness" of the enterprise. Indeed, the size of an SME implies few hierarchical levels, the centralisation of the management, informal relationships based on trust development, limited internal resources, and low standardisation of the processes. Together, these determine the specific status of SMEs as companies having a typological diversity: it is difficult to classify a specific SME in a category because each SME has its own constructive and functional features (Nicolescu, 2009) due to the intuitive organisation built inside the enterprise.

The literature supposes a higher need for support of SMEs because of their resources' gap (Kent, 1994; Viljamaa, 2011). Boter and Lundstrom (2005) refer to the notion of smallness as a reason for this lack of resources: the smaller the enterprise, the fewer resources it has. In their study, they focus on the size dimension of small businesses to analyse how SMEs use the support services available on the market in Sweden. "The arguments from theory that small firms have a weak resource base and need external support does not translate into the smallest micro companies as the most intensive users of external support services." (Boter \& Lundstrom, 2005: 254).

In recent years, the literature has taken an entrepreneurial approach ${ }^{3}$ by focusing more on the support dedicated to the manager than to the company. This can be explained by the important role that the manager ${ }^{4}$ has in an SME, where the power is centralised and, thus, the manager is quite the unique decision-maker (Gervais, 1978; Julien \& Manchesnay, 1988). Some small companies are also owner-managed, thus the attitude towards external advisors can be different according to the owner's profile. In general, Damanpour and Schneider (2009: 496) highlighted that "manager characteristics influence the adoption of innovation" in organizations. Consequently, support should be more focused on the manager, as Boter and Lundstrom (2005: 245) suggested by raising the question of "how to develop support structures for creating the necessary skills for entrepreneurs". An "entrepreneur" approach in providing support can be an advantage: the support provider will make his recommendations directly to the manager and will not have to deal with several hierarchical levels. As Gilbert et al. (2006: 931) highlighted, doing business with a top management team, including several members, is more difficult and takes more time because the personal, educational, and experience background of each of them lead to disagreements between the team members. In this sense, providing support in an SME can be perceived as easier than doing it in a large firm, where the management is not centralised and where there are several decision-makers.

Nonetheless, this can be a limitation of the demand for support, as it will depend on the entrepreneurial spirit of the single manager. Lightfoot (1998: 237) argued that "reluctance to accept external support has its roots in small business-owner psychology". This idea is supported by Gilbert et al. (2006: 930), who highlight the important influence of the character

\footnotetext{
${ }^{1}$ Cf. among others, the International Journal of Small Business in 1982; the Journal of Small Business and Entrepreneurship in 1982; the Journal of Entrepreneurship and Regional Development in 1987; the French Revue Internationale PME in 1988; the Small Business Economics in 1989 (Torrès, 1997).

${ }^{2}$ Cf. among others, the works of Gervais, 1978; Kalika, 1988; Julien \& Manchesnay, 1988; and Nicolescu, 2009.

${ }^{3}$ For a detailed review of the entrepreneurial profile and the goals of the owner-manager, see St-Pierre and Cadieux (2011).

${ }^{4}$ For a focus on the manager and his role on SME's strategic choices, see Chabaud and Sammut (2016).
} 
traits of the entrepreneur on the firm's growth. Also, the entrepreneurial spirit of the ownermanager can have a direct impact on the management behaviour and attitude at risk of the SME and, thus, lead to reluctance, and even a resistance, to contract external support services (North et al., 2001).

The autonomy propensity and the independent entrepreneurial spirit are among the key characteristics of the owner-manager (Curran, 2000; Gilbert et al. 2006; Lightfoot, 1998; Van Gelderen \& Jansen, 2006). As a consequence, this autonomy propensity in SMEs can be a reason why the demand from SME owner-managers for external support is weak. Thus, one reason why SMEs do not use external consulting is the fear of losing their autonomy (Curran, 2000; North et al., 2001).

The question about the sector and industry specialisation is also raised, as the literature recognises the importance of the environment in which SMEs are located. Taking the example of the competencies required for a small high-tech growth business manager as opposed to a shopkeeper, Gibb (2000) argued that the competencies required will depend upon the "sector" of the SME. On the one hand, Curran (2000) highlighted that "sector ignorance" can be alleviated by targeted support. On the other hand, Nicolescu (2009) underlined that support providers do not specialise in a specific sector or industry because of the typological diversity of SMEs. Thus, according to him, the heterogeneity of SMEs does not allow a specification of support providers to typical SMEs' organisational system, as they all differ from each other.

Torrès and Plane (1998) questioned the specificities of SMEs rather than suggesting an adaptation by the support providers. Indeed, they highlighted the contradiction between the specificities of SMEs (such as informal management and centralisation) and the consulting market that requires more formalisation and a decentralisation of the management in order to be efficient. This contradiction underlines the notion of the specificity paradigm of SMEs. To move beyond it, they suggested a denaturation of traditional SMEs thanks to support providers in order to become what they defined as the managerial SME: an SME working as a large company with decentralisation, more formalisation, and planning. Nonetheless, this would require an attitude at change from SMEs, going beyond the obstacle of organisational inertia (Hannan \& Freeman, 1977, 1984, 1989; Hannan et al., 2004; Hannan, 2005).

Last but not least, lack of theory and understanding can also be seen as one of the reasons for the weak demand for external support. Based on the work of Gorb et al. (1981), O'Regan and Ghobadian (2004: 64) highlighted the "paucity of research in general on SMEs and consequently a lack of understanding of their needs and requirements". Moreover, Curran (2000: 44) considered the lack of theory as one of the main reasons why small business owners are reluctant to trust service providers. He clearly expressed this idea, stating "small businesses are not large business scaled down, and textbook and large enterprises' good practice is often poorly suited to the needs of small businesses". Furthermore, support services offered on the market have the aim to allow the growth of performance of SMEs (Srinivasan, 2014). Otherwise, growth can be influenced by several different factors. In such a context, consultants cannot necessarily take benefits from general economic theories or models (Gibb, 2000).

\section{The pivotal role played by trust and social networks}

The literature underlines the importance of the relationship and trust between the support provider and the SMEs' owner-managers (Carey \& Tanewski, 2016; Mole, 2002; Mughan et al., 2004). Mole (2002: 156) describes the advisor as "challenging the managing directors in their castle". With a different perception, Ramsden and Bennett (2005: 228) also insist on the importance of the relationship between the two counterparties by highlighting that the success of the impact of advice, as a result of a joint activity, depends on "a combination of taskinteraction, where the client and advisor exchange information on problems to be solved and means to accomplish them, with personal-interaction, where the client's well-being is improved". Trust-based interpersonal relationships are pivotal: as our analysis on the case of Drôme will show, consultants need to gain credibility and confidence in front of SMEs if they 
wish to be viewed as trustworthy. Trust can be defined as confidence in one's expectations or in the goodwill of the partner: personal embeddedness is a necessary condition. Trust implies mutual confidence, a lower level of monitoring and the expectation that the partner will not behave opportunistically (Ring, Van de Ven, 1992; Dyer, Chu, 2003; Puranam, Vanneste, 2009). Trust is the glue that keeps together the business partners (Nooteboom, Noorderhaven, 1997). Vedel and Gabarret (2014) even argued that trust plays a role of mediator, in the context of French business incubators, between the contract and information disclosure and knowledge acquisition.

Generally speaking, commitment, coordination and trust are considered in the literature as essential elements for partnerships success. Communication, collaboration and integration are required elements for maximizing the synergy (Revilla et al., 2005). Among others, Sherwood and Covin 2008, Bruneel et al. 2010, Bjerregaard 2010 and Niedergassel, Leker 2011 have highlighted the role and condition of trust between partners, their interdependency, the frequency of communication and closeness of partners: all these elements are vital for the success of an industrial alliance (Benghozi, Salvador, 2014). Nonetheless, building reputation, trust and legitimacy is a process that takes a lot of time (Chen, Wang, 2008). Initial distrust (Connelly et al., 2012) can be overcome only through stable and effective networks built on a long-lasting process that requires time, perseverance and patience (Salvador et al., 2014). Repeated interactions are necessary. Gulati (1995) even argued that trust is enhanced by familiarity and repeated ties that make it possible to predict others' actions. When we talk about the notion of strength of interpersonal ties, we refer to the definition provided by Granovetter (1973: 1361): "the strength of a tie is a (probably linear) combination of the amount of time, the emotional intensity, the intimacy (mutual confiding), and the reciprocal services which characterize the tie". Personal ties and connections built upon trust and closeness characterize social networks: Coleman (1988) argued that networking is an effective method for acquiring pivotal information that otherwise would be more expensive to acquire. And according to Morgan and Hunt (1994: 23), successful relationships marketing require cooperative behaviors led by "commitment and trust": "a committed partner wants the relationship to endure indefinitely and is willing to work at maintaining it". Nooteboom, and Noorderhaven (1997) talk about institutionalization (through repeated interactions) and habitualization (through habits formation) as two main dimensions of trust building.

As shown by Salvador et al. (2014: 372) about European SMEs willing to enter the Brazilian market, even if the Internet and information and communication technologies (ICTs) have partially substituted or completed physical proximity, the building of trust and legitimacy still requires personal contacts and long-lasting working relationships have to be nurtured to allow for trust building through a process in which "network creation" is the condicio sine qua non.

Starting from these assumptions and these different and/or complementary perspectives, our analysis aimed to contribute to the understanding of the actual SMEs' "practices and perceptions" (Sturdy, 1997) of the consultancy market through an investigation focused on a French case-study. As highlighted in the following sections, the results from a recent questionnaire specifically addressed to SMEs' managers enable us to feed the open debate about the relationship between SMEs and consultants through providing interesting and unexpected findings.

\section{Methodology}

To understand the point of view of SMEs regarding the consultancy market, a questionnaire was addressed exclusively to managers of SMEs in the department of Drôme. The choice of a focus on a very specific French area of analysis meets the need highlighted by Sturdy (2011) about adequate context research basis ${ }^{1}$ and we follow Hlady Rispal and Jouison-

\footnotetext{
1 "In particular, there is a distinct lack of comparative and historical research which explores conditions where consultancy is/was not used, including where it is actively rejected", (Sturdy, 2011: 527).
} 
Laffitte (2015) with an exploratory approach through a qualitative method ${ }^{1}$ (i.e. cluster analysis technique), taking into account that "qualitative study can help, first of all, to better understand a phenomenon" (Degeorge, 2015: 8). The questionnaire was fully answered by 38 respondents $^{3}$ between September and October 2015. To find a suitable sample of companies, the Chamber of Commerce and Industry (CCI) of Drôme department was contacted. Public information from the CCI, as well as formal and informal contacts, helped in the building of a list of local SMEs. Furthermore, the Altarès ${ }^{4}$ database was also used to complement our data. We tried to select companies from varied sectors to improve and justify the representativeness of our sample (Jack et al., 2008). Last but not least, five additional face to face interviews have been undertaken in September-October 2015 with consultants dealing in the department of Drôme: their point of view about their relationship and constraints with clients like SMEs has been useful for building the final version of the questionnaire and for nurturing the discussion of results from the SMEs' investigation.

The questionnaire was divided into three different sections:

1) General information about the respondent and the company, with questions about respondent's position in the company, the educational level, the languages spoken, the sector of the company, the year of creation, the number of staff, and the level of turnover.

2) The consulting market perception with questions about the domains of advice the SME asked, frequency and satisfaction of the received support, the suggestions of the respondent to improve the consulting market, the reasons why the SME does not invest (more) in support services, the specific needs in advice, and the budget that the company would be ready to invest in such services.

3) The potential factors impacting the demand, with questions about the kinds of institution the SME would trust more and the most important factors in the choice.

A cluster analysis ${ }^{5}$ enabled the grouping of the different types of SMEs in order to define market segments for the support providers.

Several different methods of cluster analysis exist; two-step clustering, which combines hierarchical and non-hierarchical methods, was finally chosen.

The first step was to determine the clustering variables used for the cluster analysis. Kline (1994) suggests a sample size at least twice as large as the number of variables. Following this approach, 18 clustering variables have been selected. To select the variables, we decided to start from the main findings of the questionnaire, as described in the following descriptive statistics section. Table 5 in the Annex lists the 18 clustering variables and their characteristics.

First, an analysis of the correlations between clustering variables was conducted; no problems of correlation emerged.

Then, a two-step cluster analysis was undertaken, as the variables were both continuous and ordinal with different scale levels (Chiu et al., 2001; Norusis, 2009; Mooi \& Sarstedt, 2011; Pullen et al., 2008). The distance measure used was the log-likelihood criterion.

The best number of clusters was identified through the Akaike's information criterion (AIC) and Bayes information criterion (BIC), which are measures "of goodness-of-fit and are used to compare different solutions with different numbers of segments" (Mooi \& Sarstedt,

\footnotetext{
${ }^{1}$ For a careful review of qualitative methodology of research in entrepreneurship, see Degeorge (2015).

2 Authors' personal translation from the original sentence : «L'étude qualitative peut permettre, tout d'abord, de mieux appréhender un phénomène ».

${ }^{3}$ We can reasonably consider this number as appropriate for a case-study analysis (cf Yin, 2003 and Gioia, et al., 2013). Furthermore, also Sturdy (1997: 390) focused his analysis on 39 returned questionnaires about the commissioning and use of consultants and attitudes towards them in the UK.

${ }^{4}$ Altarès is a database offering general information about more than 20 million French companies.

${ }^{5}$ Cluster analysis is a "convenient method for identifying homogeneous groups of objects called clusters. Objects (or cases, observations) in a specific cluster share many characteristics, but are very dissimilar to objects not belonging to that cluster" (Mooi \& Sarstedt, 2011: 238).
} 
2011: 279). Following Mooi and Sarstedt's (2011) recommendations, in order to evaluate the stability of our results we ran the cluster analysis twice with the AIC and BIC criteria. No "outliers" cluster was detected.

The following section will illustrate the descriptive results from the questionnaire investigation as well as the findings coming from the cluster analysis undertaken.

\section{Results: Descriptive statistics from the questionnaire}

The sectors in which the 38 respondents are active vary widely: most of the respondents work in the wholesale and retail trade (eight companies), manufacturing industry (seven) and real estate, renting, and business activities (five). Agriculture, construction, transport, health, and social works follow (three companies for every sector).

In terms of company age, 16 companies were created during these last 10 years, while five were founded before 1975, 10 between 1976 and 2000, and seven between 2001 and 2005.

The results suggest that $13 \%$ of the respondents (five companies) never used support services against 87\% (33 companies) having a prior experience with external support. SMEs have been divided in group A (in blue colours), meaning companies that already contracted support services, and group B (in red colours), meaning companies that never contracted support services.

The analysis of the main questions of the questionnaire reveals the preference for some kinds of consultancy (see Figure 1 for details). The frequency of use is between rarely to regularly and the satisfaction level is quite good. The investigation about reasons for not contracting (more or at all) external support services revealed that SMEs favour internal resources and fear finance constraints (cf. Figure 2). Finally, the questionnaire aimed at highlighting which factors would enhance the demand for support services. Surprisingly, web platforms, business schools and banks' office for company services are the least preferred structures. The most preferred are institutions specialised in the SME sector, independent consultants supporting the company on a long-term basis and private entities with the required specialization. The experience of the advisor and the relationship and trust built between the SME and the consultant are the most important factors when choosing external services (see Figure 3).

5.1 SMEs' evaluation about their need for consulting support: the leading role played by consultancy in finance and accounting

Consultancy in finance and accounting is the domain that is most used by the respondents (17 companies), before management and organisation consultancy (11 companies), information technology (nine), marketing \& communication consultancy (nine), and business development (eight). Human resources and recruitment consultancy is the least used (only four companies).

Furthermore, the results highlighted that $92 \%$ of the respondents use three or fewer kinds of support services in their company. Only three companies use more than three kinds of consultancy, including a unique one using all of the seven kinds of consultancy (see Figure 1) suggested in the questionnaire.

Two specific questions were addressed to companies which already contracted external support services (33 companies). These questions were about the frequency of use and the satisfaction level. Frequency has been measured using a 3-point Likert scale. ${ }^{1}$ Globally, most SMEs that already contracted support services use them "rarely" to "regularly". Human resources \& recruitment and finance \& accounting are used "regularly" on average (mean values $=2$ ). Regarding the satisfaction level, the question was asked on a 5-point Likert scale. ${ }^{2}$

\footnotetext{
${ }^{1}$ (1=Rarely; 2=Regularly; 3=Often)

${ }^{2}$ ( $1=$ very dissatisfied; $2=$ somewhat dissatisfied; $3=$ neutral; $4=$ somewhat satisfied; 5=very satisfied)
} 
According to the results, the global satisfaction of support services used is between neutral and somewhat high, with a mean of the mean values of 3.86/5. All the means regarding the satisfaction level are higher than 3, meaning that, on average, no kind of consultancy was perceived negatively by the respondents. The domains in which the respondents were the most satisfied are marketing \& communication, human resources \& recruitment, and finance \& accounting, with mean values of 4 for each one.

We thought it relevant to ask the respondents assessing their need for support in order to deny the possibility of market saturation as a reason for the low demand for support. To achieve this aim, a question was addressed using a 5-point Likert scale for each of the consultancy domains suggested in the questionnaire (see Figure 1). As expected, the results highlight that, on average, SMEs that never contracted support services (Group B, in red) consider having a less important need for support than SMEs that already contracted such services (Group A, in blue).

Figure 1: How would you evaluate your need for consulting support?

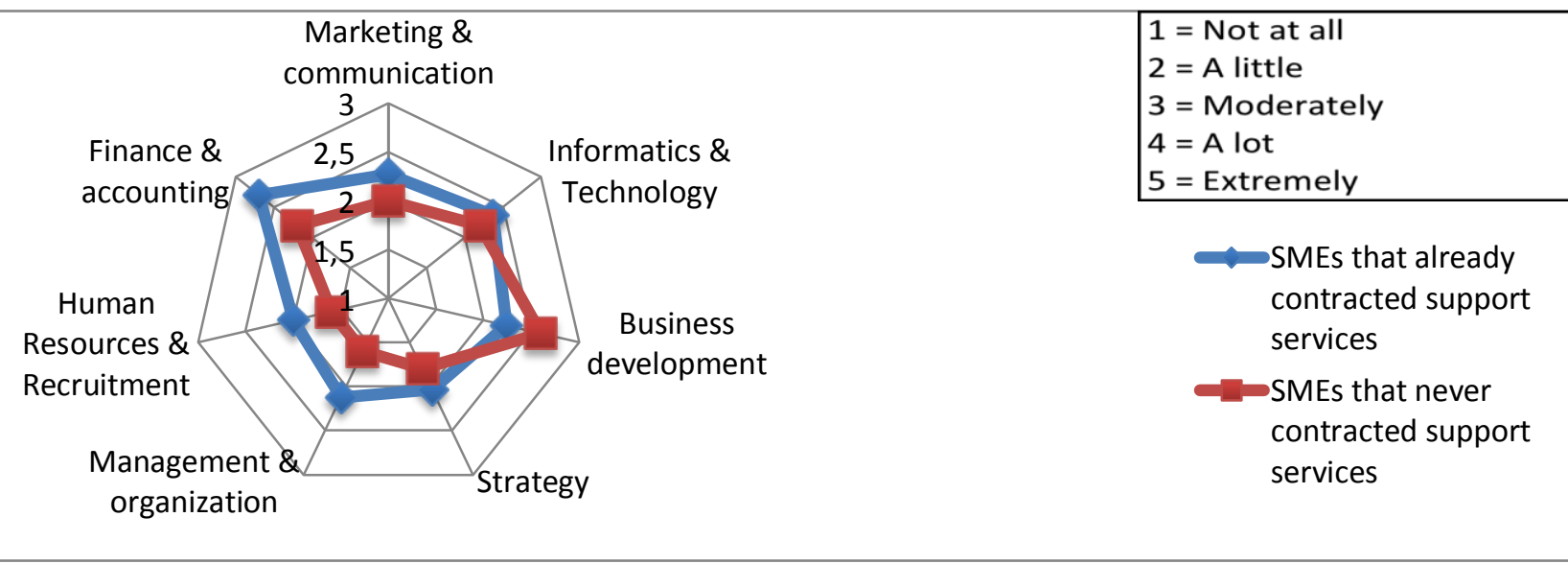

Nonetheless, the domain in which group B expressed higher needs than group A is business development. Group A underlined more need in finance \& accounting (2.7/5).

The figure also shows that none of the mean values is higher than 3 , meaning that all the respondents evaluate their need for support as moderate. In any case, on average, no domains were indicated as being not needed at all, thus excluding the possibility of market saturation.

5.2 Possible reasons for not contracting external support services: a willingness to favour internal resources and a finance gap

A specific question aimed at understanding why SMEs' managers do not contract (more or at all) external support services, by suggesting some possible reasons with a 5-point Likert scale (from $1=$ Strongly disagree to $5=$ Strongly agree) ${ }^{1}$.

Figure 2: Why do you not use (more/any) external support services?

\begin{tabular}{|l|l|}
\hline Specificity \& & $\begin{array}{l}1=\text { Strongly disagree } \\
2=\text { Somewhat disagree } \\
3=\text { Neutral } \\
4=\text { Somewhat agree } \\
5=\text { Strongly agree }\end{array}$ \\
SMEs that already used \\
support services (33 \\
companies) \\
SMEs that never used \\
support services (5 \\
companies)
\end{tabular}


Figure 2 shows the mean values for each of the suggestions, with a distinction between SMEs that already contracted support services (Group A in blue) and SMEs that did not (Group B in red). As expected, SMEs that never used support services consider these reasons at a higher level than SMEs that already used support services. But disappointing past experiences are not considered as a main reason for not contracting more support services (mean values 2.6). Both groups $\mathrm{A}$ and $\mathrm{B}$ also agree at the same level about the "specificity and complexity of the company" reason (respectively 3.03/5 and 3.4/5) and about the "time constraint" problem (respectively 3.09/5 and 3.6/5). Furthermore, the most important reasons for not contracting more support services are the willingness to favour internal resources and the limited financial means for both the groups (higher for Group B). Interestingly, the perception about lack of trust in external consultants revealed that group B agreed between "Neutral" to "Somewhat" (3.4/5), while group A chose "Somewhat disagree" (2/5). Perceptions also differ regarding "Contracting external support services would lead to radical changes within your company, changes that your company is not ready to face today"; group A was between "strongly" to "somewhat" disagree (1.91/5) and group B was neutral (3/5).

5.3 Possible factors enhancing the demand for support services: experience, relationship and trust

Following the analysis of the possible reasons for not contracting external support services, we also tried to determine which factors would enhance the demand for support services. We considered interesting to determine whether the kind of support structure can have an impact on the willingness of SMEs' managers to invest in support services. Thus, we asked the respondents to classify different structures of support providers by order of preference. The questionnaire included the same question twice (business development and organisation \& management), thus asking preferences about the structure or sources of support, but with a distinction about a selection of consultancy domains. ${ }^{1}$

Globally, for both the questions, the most preferred suggestions were "an institution specialised in the sector of activity of the SME", "an independent consultant accompanying the company on a long-term basis", "a private entity specialised in the kind of support that the company is looking for", and "support services offered by public entities".

Thus, the least preferred were "a web platform" (last position), "business school" and "banks' office for company services". Furthermore, when checking the total mean values, slight differences exist between the four first-ranked suggestions (until 0.38), while differences in rank means are much higher between ranks 4 and 5 (1.74), attesting that the "banks' office for company services", "web platform", and "business school" are far away in terms of preferences.

Finally, a question was addressed to all the respondents about the factors influencing their choice when looking for a support provider. Respondents were asked to indicate the degree of importance (from $1=$ Not important at all to $5=$ Very important) for each of the suggested factors. ${ }^{2}$ Figure 3 presents the results with the rank means for each of the factors suggested, with

\footnotetext{
${ }^{1}$ The respondents had to rank from most to least preferred (1 indicated the most preferred and 7 the least preferred) the suggested structures if they would need support services in business development and (in a different question) in organisation \& management. The repetition of almost the same question was decided in order not to bias the results with a specific consultancy domain. The different schemes offered in the questionnaire were the following: Bank: banks' office for company services; Public entities: support services directly offered by the CCI or other public entities; Consultancy domain: a private entity specialised in the support that the SME is looking for; Sector of activity: a private entity specialised in the SME sector of activity; Long-term consultant: an independent consultant accompanying the SME on a long-term basis; Web platform: a web platform offering online support to professionals; Business school: a business school working on the company problem to provide possible solutions.

${ }^{2}$ Price: the service's price; Time involvement: time that the consultant has to spend to solve the problem; Experience in the sector of activity: the consultant's experience in the sector of activity; Experience in the consultancy domain: the consultant's experience in the consultancy domain needed; Consultant's
} 
a distinction between SMEs that already contracted support services (Group A in blue) and SMEs that did not (Group B in red).

Figure 3: Suppose that you need an external consultant for a purpose of your company, at which level would the following factors influence your choice?

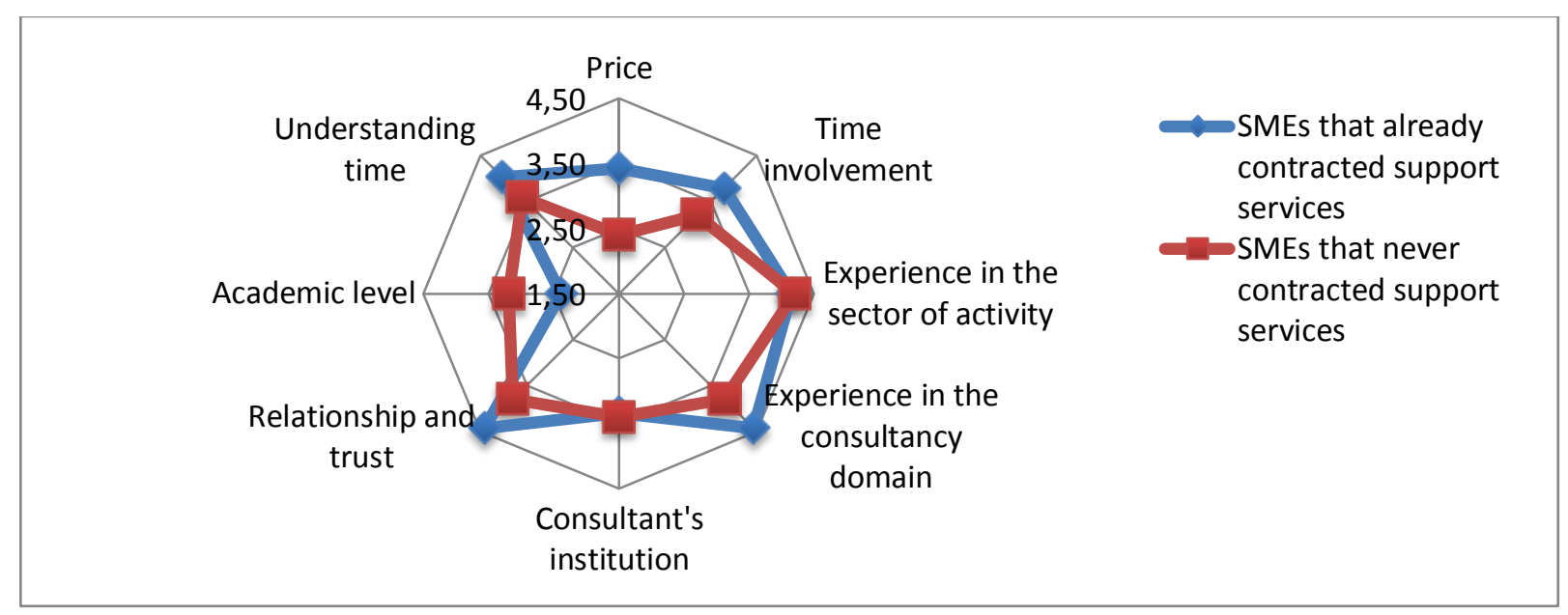

Globally, the most suggested factors seem to be moderately important, according to our sample, with rank means superior to 3. Surprisingly, SMEs that never contracted support services (Group B in red) indicated, on average, an importance of $2.4 / 5$ for the price (thus being the lowest important factor), while the same respondents indicated the limited financial resources as one of the most important reasons for not contracting support services at all (Figure 2). According to SMEs that never contracted support services, the three most important factors when choosing an external support consultant would be the experience in the sector of activity of the company (4.2/5), the experience in the consultancy domain (3.8/5), and the relationship and trust the SME has with the consultant (3.8/5).

SMEs that already contracted support services (Group A in blue) consider the same three factors as the most important ones, with the highest importance for the "relationship \& trust" and "experience in the consultancy domain" factors (both 4.42/5), closely followed by the "experience in the sector of activity" (4.2/5). Therefore, by providing support on a long-term basis and being specialised in the sector of activity of SMEs, the consultants are supposed to meet the demand of SMEs' managers at a higher level. Trust and experience seem to be the keywords.

\section{Cluster analysis results: three clusters with different orientations}

Following the descriptive statistics of the questionnaire sections, it was useful to complement these first results with a focus on the SMEs' practices and perceptions of the consultancy market. The cluster analysis aimed at understanding and making clearer the specific components of the variables distinguishing the relationship between the consultancy market and SMEs. More precisely, it helped to highlight three main clusters, identified as follows. The two-step cluster analysis suggests a number of three clusters (with a consistency measure of 0.3 , cf. Figure 4 in Annex). Cluster 1 counts 14 out of the 38 respondents (36.8\%), Cluster 2 includes 18 respondents $(47.4 \%)$, and Cluster 3 has six respondents (15.8\%). To understand how the

institution: the institution the consultant works for; Relationship and trust: the relationship and the feeling that the company has with the consultant in terms of trust; Academic level: the academic level of the consultant; Understanding time: the time that the consultant spends to understand the problems of the company, even before signing the contract. 
clusters were determined, we looked at the most important variables that influenced the determination of clusters. In line with the descriptive statistics, the variables linked to support services provided by CCIs or other public entities for support in organisation \& management (BINMana_Public, $\mathrm{F}=75,757$ ), a private entity specialised in the sector of activity for organisation \& management (BINMana_SectorSpecial, $\mathrm{F}=45,465$ ), and an independent consultant accompanying the SME on a long-term basis for support in organisation \& management (BINMana_IndepentdentLT, $\mathrm{F}=25,053$ ) are the most significantly influential ones (see Table 1 ANOVA in Annex).

Figure 5: Analysis of the clusters' content

\section{Clusters}

Input (Predictor) Importance $\square 1,0 \square 0,8 \square 0,6 \square 0,4 \square 0,2 \square 0,0$

\begin{tabular}{|c|c|c|c|}
\hline Cluster & 1 & 2 & 3 \\
\hline Size & $36.8 \%$ & $47.4 \%$ & $15.8 \%$ \\
\hline \multirow[t]{18}{*}{ Inputs } & $\begin{array}{c}\text { BINMana_Sector } \\
\text { Special }\end{array}$ & BINMana_Public & $\begin{array}{c}\text { BINMana } \\
\text { IndepentdeñtLT }\end{array}$ \\
\hline & BINMana_Public & $\begin{array}{c}\text { BINMana_Sector } \\
\text { Special }\end{array}$ & \begin{tabular}{|c|} 
BINFactor_Relationshi \\
$\mathrm{p}$
\end{tabular} \\
\hline & BINCom_Public & $\begin{array}{c}\text { BINMana } \\
\text { IndepentdeñtLT }\end{array}$ & $\begin{array}{c}\text { BINFactor_Time } \\
\text { Involvement }\end{array}$ \\
\hline & $\begin{array}{c}\text { BINFactor_Time } \\
\text { Involvement }\end{array}$ & BINCom_Public & BINCom_Indepentdent \\
\hline & $\begin{array}{c}\text { BINReason_Internal } \\
\text { Resources }\end{array}$ & $\begin{array}{c}\text { BINCom_Indepentdent } \\
\text { LT }\end{array}$ & BINFactor_Price \\
\hline & $\begin{array}{c}\text { BINCom_Domain } \\
\text { Special }\end{array}$ & BINReason_Distrust & BINReason_Distrust \\
\hline & BINCom_SectorSpecial & $\begin{array}{c}\text { BINFactor_Relationshi } \\
\mathrm{p}\end{array}$ & Need_MeanValues \\
\hline & Need_MeanValues & $\begin{array}{c}\text { BINReason_Internal } \\
\text { Resoưrces }\end{array}$ & BINMana_Public \\
\hline & \begin{tabular}{|c|} 
BINFactor \\
Understanding TIme \\
\end{tabular} & BINCom_SectorSpecial & $\begin{array}{c}\text { BINMana_Sector } \\
\text { Special }\end{array}$ \\
\hline & \begin{tabular}{|c|} 
BINFactor_Relationshi \\
$\mathrm{p}$
\end{tabular} & $\begin{array}{c}\text { BINFactor_Academic } \\
\text { Level }\end{array}$ & $\begin{array}{c}\text { BINFactor } \\
\text { UnderstandingTIme } \\
\end{array}$ \\
\hline & BINFactor_Price & $\begin{array}{c}\text { BINCom_Domain } \\
\text { Special }\end{array}$ & $\begin{array}{c}\text { BINCom_Domain } \\
\text { Special }\end{array}$ \\
\hline & $\begin{array}{c}\text { BINMana } \\
\text { IndepentdeñtLT }\end{array}$ & BINFactor_Price & $\begin{array}{c}\text { BINFactor_Academic } \\
\text { Level }\end{array}$ \\
\hline & $\begin{array}{c}\text { BINFactor_Academic } \\
\text { Level }\end{array}$ & $\begin{array}{c}\text { BINReason No } \\
\text { Financial }\end{array}$ & $\begin{array}{c}\text { BINReason_No } \\
\text { Financial }\end{array}$ \\
\hline & BINReason_Distrust & Need_MeanValues & $\begin{array}{c}\text { BINReason_Internal } \\
\text { Resources }\end{array}$ \\
\hline & $\begin{array}{c}\text { BINCom_Indepentdent } \\
\text { LT }\end{array}$ & $\begin{array}{c}\text { BINFactor } \\
\text { UnderstandingTIme }\end{array}$ & BINCom_SectorSpecial \\
\hline & BINReason_NoTime & $\begin{array}{c}\text { BINMana_Domain } \\
\text { Special }\end{array}$ & $\begin{array}{c}\text { BINMana_Domain } \\
\text { Special }\end{array}$ \\
\hline & $\begin{array}{c}\text { BINReason No } \\
\text { Financial }\end{array}$ & $\begin{array}{l}\text { BINFactor Time } \\
\text { Involvement }\end{array}$ & BINReason_NoTime \\
\hline & $\begin{array}{c}\text { BINMana_Domain } \\
\text { Special }\end{array}$ & BINReason_NoTime & BINCom_Public \\
\hline
\end{tabular}

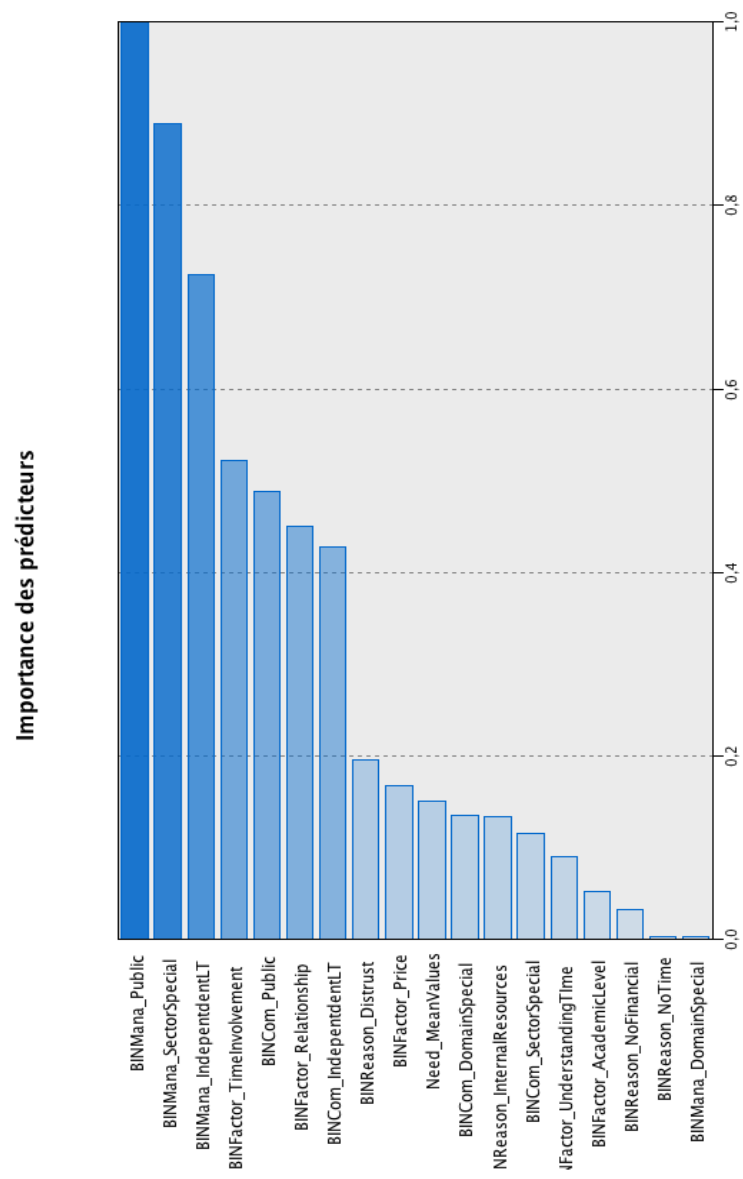

Cluster 1 seems to regroup mainly respondents preferring public institutions (mean $=0,86$ ), while Cluster 2 gathers mostly respondents not preferring public institutions (mean=0,17) but looking at relationships building (mean=0,94). Cluster 3 regroups respondents focused on the use of internal resources (mean $=0,67)$.

Figure 5 presents, on the left-hand side, the global importance attributed to each variable in the determination of the clusters: the darker the color, the more important its global impact in the determination of the clusters. The importance of predictors is also readable by cluster: the uppermost the variable is in a cluster, the more significant its role within the cluster, and vice versa. The right-hand side of the graph ranks the variables according to their importance. 
The different weight of the several variables in the three clusters makes it possible to describe in detail the content and characteristics of every cluster as identified by the two-steps cluster analysis results.

Cluster 1: Public entities oriented

Cluster 1 is characterised by high preference for public entities to contract support services. Looking for support in organisation \& management, the respondents are not searching for institutions that are experts in the specific sector of activity of the SME (mean value 0). Furthermore, the respondents have different preferences for an institution specialised in the consultancy domain provided according to the kind of support required. Indeed, Cluster 1 prefers this kind of institution more for organisation \& management (mean=0.79) than for business development (mean=0.43). Thus, Cluster 1 regroups respondents that mostly prefer public institutions but not necessarily specialised in the sector of activity of the SME.

The time involvement and the understanding time spent by the consultant, as well as the relationship that the SMEs' managers build with the consultant in terms of trust, are the most important factors when choosing a specific support provider. Also, on average, the SMEs' managers of Cluster 1 are not sensitive to the academic level of the consultant (mean=0.21).

The sector of activity of the respondents varies widely for this cluster, as well as the date of the creation of the company (with a range from 1963 to 2013). The cluster comprises mostly microenterprises (57\%) but also small (14\%) and medium (29\%) enterprises.

Cluster 1 also regroups respondents with the highest mean values of needs. As we have seen in the descriptive analysis of the questionnaire, the perception of the company's needs remains relatively low. Anyway, the lack of need is not a reason for not contracting support services (respondents of this cluster mainly disagreed with this potential reason in the questionnaire).

The main constraints are the limited financial resources of the company, as well as the lack of time of the SMEs' managers.

Based on these main results, Cluster 1 can be labelled "Public entities oriented". Table 2 summarises the main characteristics of Cluster 1.

Table 2: Main characteristics of Cluster 1

\begin{tabular}{|c|c|c|}
\hline & \multicolumn{2}{|c|}{ Cluster 1: 'Public entities oriented' (14 SMEs) } \\
\hline $\begin{array}{l}\text { Institution } \\
\text { preferences }\end{array}$ & $\begin{array}{l}\text { Support in organisation \& } \\
\text { management } \\
\text { 1) Public entities (++++) } \\
\text { 2) Specialised in the consultancy } \\
\text { domain (++) } \\
\text { 3) Long-term independent } \\
\text { consultant (+) } \\
\text { 4) Specialised in the sector of } \\
\text { activity (----) } \\
\text { Institution is not an important fac }\end{array}$ & $\begin{array}{l}\text { Support in business development } \\
\text { 1) Public entities (+++) } \\
\text { 2) Long-term independent consultant (+) } \\
\text { 3) Specialised in the sector of activity (+-) } \\
\text { 4) Specialised in the consultancy domain (-) } \\
\text { tor when choosing the consultant (+) }\end{array}$ \\
\hline $\begin{array}{l}\text { Reasons for no } \\
\text { more support }\end{array}$ & $\begin{array}{l}\text { Lack of finance }(+) \\
\text { Lack of time }(+)\end{array}$ & $\begin{array}{l}\text { Willingness to favour internal resources (--) } \\
\text { Distrust of the consultant (--) }\end{array}$ \\
\hline $\begin{array}{c}\text { Factors } \\
\text { influencing the } \\
\text { choice of a } \\
\text { specific consultant }\end{array}$ & $\begin{array}{l}\text { Consultant's time involvement } \\
\text { to provide the service }(+++) \\
\text { The relationship and trust that } \\
\text { the manager has with the } \\
\text { consultant }(+++) \\
\text { The time that the consultant } \\
\text { spends understanding the } \\
\text { company }(+++)\end{array}$ & $\begin{array}{l}\text { he price (+-) } \\
\text { The consultant's academic level (--) }\end{array}$ \\
\hline
\end{tabular}




\begin{tabular}{|c|c|}
\cline { 2 - 2 } & Average need for support between "a little" and "moderately" \\
The lack of need is not a reason for not contracting more support \\
information \\
Companies created between 1963 and 2014 \\
Micro-enterprises: $57 \%$ \\
Small enterprises: $14 \%$ \\
Medium enterprises: $29 \%$ \\
\hline
\end{tabular}

Cluster 2: Personal relationship oriented

Cluster 2 is characterised by a deep relationship and trust with the consultant, as well as by a lack of preference for public entities. All the respondents ranked an independent consultant providing support on a long-term basis as one of the most preferred (mean value=1). Also, this is the most influential factor when choosing a specific consultant, as well as time spent by the consultant understanding the company and providing support. The price is perceived as somewhat important, while the consultant's academic level does not matter.

The weak demand is mainly explained by the limited financial resources and time constraints of the manager. Besides, managers show some propensity to favour internal resources rather than external ones, which is another reason for the limited demand.

In this cluster, the respondents favour the relationship they have with the consultants, and, thus, they are looking for trust and a real collaboration on a long-term basis.

Based on these main results, we can label this cluster "personal relationship oriented".

Table 3 summarises the main characteristics of Cluster 2.

Table 3: Main characteristics of Cluster 2

\begin{tabular}{|c|c|c|}
\hline & \multicolumn{2}{|c|}{ Cluster 2: 'Personal relationship oriented' (18 SMEs) } \\
\hline $\begin{array}{l}\text { Institution } \\
\text { preferences }\end{array}$ & $\begin{array}{l}\text { Support in organisation \& management } \\
\text { 1) Long-term independent consultant }(++++) \\
\text { 2) Specialised in the sector of activity }(+++) \\
\text { 3) Specialised in the consultancy domain }(++) \\
\text { 4) Public (---) } \\
\text { Institution is somewhat important }\end{array}$ & $\begin{array}{l}\text { Support in business development } \\
\text { 1) Long-term independent consultant (++) } \\
\text { 2) Specialised in the sector of activity (++) } \\
\text { 3) Specialised in the consultancy domain (++) } \\
\text { 4) Public (--) } \\
\text { when choosing the consultant (+-) }\end{array}$ \\
\hline $\begin{array}{l}\text { Reasons for } \\
\text { no more } \\
\text { support }\end{array}$ & $\begin{array}{l}\text { Lack of finance }(+) \\
\text { Willingness to favour internal resources }(+) \\
\text { Lack of time }(+)\end{array}$ & Distrust of the consultant (---) \\
\hline $\begin{array}{l}\text { Factors } \\
\text { influencing } \\
\text { the choice } \\
\text { of a specific } \\
\text { consultant }\end{array}$ & $\begin{array}{l}\text { The pri } \\
\text { The relationship and trust that the manager } \\
\text { has with the consultant }(+++) \\
\text { The time that the consultant spends } \\
\text { understanding the company }(++) \\
\text { Consultant's time involvement to provide the } \\
\text { service (+) }\end{array}$ & $\begin{array}{l}\text { The }(+-) \\
\text { The consultant's academic level (---) }\end{array}$ \\
\hline $\begin{array}{l}\text { General } \\
\text { information }\end{array}$ & $\begin{array}{r}\text { Average need for support betw } \\
\text { The lack of need is not a reason } \\
\text { Companies created be } \\
\text { Micro-enterprises: } \\
\text { Small enterprises: } \\
\text { Medium enterprises: }\end{array}$ & $\begin{array}{l}\text { een "a little" and "moderately" } \\
\text { for not contracting more support } \\
\text { tween } 1912 \text { and } 2014 \\
67 \% \\
17 \% \\
27 \%\end{array}$ \\
\hline
\end{tabular}

Cluster 3: Internal support oriented

Cluster 3 is characterised by micro-enterprises' managers, created in the last 10 years, that favour consultants specialised both in the sector of activity and in the consultancy domain provided. They are unwilling to trust independent consultants providing support on a long-term basis (mean value $=0$ ). This cluster gathers respondents that are on average available on a 
limited basis to contract support services. Indeed, no powerful factors are present to influence the choice of the respondent for a specific support provider. The price and the time involvement of the consultant are not even important at all, with a mean value of 0 . Furthermore, respondents do not recognise having needs for support (the average need is between "not at all" and "a little"), and most of the reasons suggested to explain the limited demand are validated by the SMEs' managers at a high level. The managers in this cluster consider their company too complex or specific to be understood by an external consultant. Thus, they would favour internal resources and somewhat distrust external consultants. Limited financial means are also a main reason explaining this reluctance (mean value of $0.83 / 1$ ). Based on these main results, we can label this cluster "Internal support oriented". Table 4 summarises the main characteristics of Cluster 3 that anyway is the smallest one.

Table 4: Main characteristics of Cluster 3

\begin{tabular}{|c|c|c|}
\hline & \multicolumn{2}{|c|}{ Cluster 3: Internal support oriented (Six SMEs) } \\
\hline $\begin{array}{l}\text { Institution } \\
\text { preferences }\end{array}$ & $\begin{array}{l}\text { Support in organisation \& management } \\
\text { 1) Specialised in the sector of activity (++) } \\
\text { 2) Specialised in the consultancy domain }(++) \\
\text { 3) Public (++) } \\
\text { 4) Long-term independent consultant (----) } \\
\text { Institution is somewhat important }\end{array}$ & $\begin{array}{l}\text { Support in business development } \\
\text { 1) Specialised in the consultancy domain (++) } \\
\text { 2) Specialised in the sector of activity (++) } \\
\text { 3) Public (+-) } \\
\text { 4) Long-term independent consultant (----) } \\
\text { when choosing the consultant (+-) }\end{array}$ \\
\hline $\begin{array}{l}\text { Reasons for } \\
\text { no more } \\
\text { support }\end{array}$ & \multicolumn{2}{|c|}{$\begin{array}{l}\text { Distrust of the consultant }(+-) \\
\text { Lack of time }(+-) \\
\text { Disappointing past experience with consultant }(+-) \\
\text { ance }(++) \\
\text { to favour internal resources }(+)\end{array}$} \\
\hline $\begin{array}{l}\text { Factors } \\
\text { influencing } \\
\text { the choice } \\
\text { of a specific } \\
\text { consultant }\end{array}$ & The time that the consultant spenc & $\begin{array}{l}\text { ds understanding the company (+-) } \\
\text { The price (----) } \\
\text { Consultant's time involvement to provide the } \\
\text { service (----) } \\
\text { The relationship and trust that the manager } \\
\text { has with the consultant (-) } \\
\text { The consultant's academic level (-) }\end{array}$ \\
\hline $\begin{array}{c}\text { General } \\
\text { information }\end{array}$ & $\begin{array}{r}\text { Average need for support bet } \\
\text { The lack of need is somewhat a reason } \\
\text { Recent companies create } \\
\text { Exclusively mi }\end{array}$ & $\begin{array}{l}\text { ween "not at all" and "a little" } \\
\text { n for not contracting more support (+-) } \\
\text { d between } 2005 \text { and } 2013 \\
\text { icro-enterprises }\end{array}$ \\
\hline
\end{tabular}

7. Discussion and some concluding remarks

The results of our analysis on French SMEs could appear a predicable outcome at first sight, but it really is not so. Following the ICT revolution and the rapid changes appearing in the Internet economy, one could expect to see new attitudes coming from flexible structures like SMEs. Actually, the SMEs of our sample still prefer to deal with physical persons, and they are not willing to trust digital solutions: surprisingly, web platforms turned out to be one of the least preferred sources of consultancy services. Yet, in the 1990s, Lauder et al. (1994: 9) highlighted that "irrespective of country, SMEs face common problems which impair both their performance and survival rate. Typically, these problems are: lack of managerial competence, under-capitalization, disadvantages of scale and failure to update market knowledge or adapt to new technologies". Today, notwithstanding the Internet revolution and the diffusion of ICTs, we 
can highlight the persistence of what North et al. (2001: 309), talking about the use of external finance, defined as the "conservative attitudes of many SME owners and managers". This creates a sort of paradoxical situation. On the one hand, SMEs are more flexible and more able to adapt to changes compared to large firms, and, as a consequence, they demand "personalised solutions", as confirmed by consultants during direct interviews (October 2015). On the other hand, SMEs seem to maintain an organisational inertia (Hannan \& Freeman, 1977, 1984, 1989; Hannan et al., 2004; Hannan, 2005) given their resistance to adopt innovative solutions offered by the ICTs, such as the use of web-based platforms for external support services.

Furthermore, the results of our analysis revealed the refusal of standardised services and the great importance played by ad hoc solutions: this means that, like in most of the sectors of the digital economy, creativity and originality will make the difference in the near future (Benghozi \& Salvador, 2015). Creative thinking is pivotal to (management) innovation (Hamel, 2006). Therefore, service providers, notwithstanding their level of education, will have more chances to convince and be trusted by SMEs' managers if they will be able to provide unique and original solutions that will help SMEs in assuring their autonomous differentiation compared to competitors. Nonetheless, these unique and creative solutions are strictly linked to the consultants' commitment of gaining SMEs' trust and building strong ties and networking (Granovetter, 1973; Coleman, 1988; Morgan, Hunt, 1994) in order to overcome the distrust (Connelly et al., 2012) and autonomy propensity of SMEs (cf following sections).

\subsection{SMEs: the contradiction between flexibility and organisational inertia}

The general aim of an SME manager who is willing to look for support from external providers is to stabilise, improve, or diversify the activity of the company. As the majority of ownermanagers consider the costs of support provided by external consultants as an extra financial cost (North et al., 2001; Mihai, 2009), SMEs need to be sure that the budget dedicated to support services will allow for an improvement of the performance of the company (Carey, 2015). Several studies have demonstrated that support from external providers can lead to higher performance of SMEs (Bennett \& Robson, 1999; Henisz \& Levitt, 2011; Mole, 2002; Scott, 2008; Xin \& Pearce, 1996), and using external advice is positively correlated to the growth rate of the SME (Bennett \& Robson, 1999; Berry et al., 2006). Carey and Tanewski (2016) focused on Australian SMEs and they found a significantly and positive association between the purchase of business advice and the competence of the external accountant as perceived by the SME. In other words, external consultants could create value for the SME through providing pivotal insights for the introduction of managerial innovations (Damanpour \& Aravind, 2012). However, these innovations would involve changes in traditional management practices, thus directly affecting the work of managers (Hamel, 2006). That's why SMEs' managers play a pivotal role in the decision of trusting external consultants. The pivotal role played by the SME manager has been underlined also by the consultants interviewed: they used the expression "multi-caps" about the manager that is in charge of everything.

Taking into account the characteristics of SMEs at a general level, one can wonder whether the specificities of SMEs are to be considered as the real limit in the support services market. Indeed, SMEs have a specific status that leads to the need of specific theory and adapted support to meet their requirements (Gibb, 2000; Torres \& Plane, 1998). Nonetheless, following the results of our analysis and the comments of the consultants interviewed, other arguments could be raised and, in particular, the contradiction between the flexibility of SMEs and the brake in responding to the actual evolving economic context completed by the persistence of an attitude at maintaining autonomy and independence.

Our analysis revealed that limited financial resources and an autonomy propensity are among the most important reasons discouraging SMEs from using external support. As also highlighted during the interviews, SMEs face difficulties in trusting external consultants because of fear of radical changes within the company. Nonetheless, SMEs recognise the need for external support and past experiences of companies that were involved with support providers provided a satisfactory result. On the one hand, the SMEs' awareness of the need for 
consultancy services has been reflected in a demand for "specialisation": the most preferred sources of support services have been identified in private entities specialised in the company's sector or in the consultancy domain required, as well as in public entities or independent consultants engaged in a long-lasting relationship (cf. Cluster 1 and Cluster 2). On the other hand, there is also still reluctance at looking for external consultancy because of financial constraints and/or an independent attitude (cf. Cluster 3, the smallest one).

As a consequence, the experience and expertise of support providers and the trust relationship (Ramsden \& Bennett, 2005; Viljamaa, 2011) built on a long-term basis with the manager of the SME make the real difference: a consultant interviewed talked about "a trustbased relationship". This confirms and deepens the findings about Australian SMEs by Carey and Tanewski (2016): they highlighted the role played by time and confidence in nurturing relationships with external advisors. Our analysis reveals that support has to be provided not only on a long-term basis and by building a trust relationship, but that a deep specialisation in the sector of activity of the SME is also required. Like consumers in the actual Internet economy, SMEs are more and more demanding and external consultants are supposed to meet each specific demand at a high-quality level. Furthermore, our findings confirm the assumption advanced by Christensen et al. (2013): "modular providers" with a specific expertise on a limited basis are going to replace general "integrated solution shops".

Last but not least, consultants are outsiders and they need to gain legitimacy facing a company: Antal and Krebsbach-Gnath (2001) even suggested that consultants should adopt a "marginal" role facing the necessary central role of the client in order to maximise organizational learning. To this aim, Sturdy et al. (2009) and Sturdy (2009) cite the strength of weak ties: we build precisely on ties and trust building in the following section.

7.2 The relationship between consultants and SMEs: the key role of strong ties and commitment for trust building

Clusters 1 and 2 clearly underlined the strong role played by trust-relationships and long-term collaborations between SMEs' managers and consultants: these Clusters comprise the majority of SMEs of our sample. Taking into account the descriptive statistics' results and the content of the Clusters regrouping the SMEs, we can highlight the pivotal role played by trust linked to strong ties built through a long process of repeated collaborations. Trust-based relationships improve the degree of collaboration and communication (Vedel, Gabarret, 2014).

Consultants need to show reliability and integrity to gain trust with SMEs. In short, SMEs may exhibit confidence towards consultants only if qualities like competence, honesty, fairness, responsibility, consistency are clearly proved (Morgan, Hunt, 1994). To this aim, consultants are expected to show empathy and share the same values of their SMEs' clients.

Trust has subjective and personal connotations; anyway, it implies to go beyond calculative self-interest and it requires familiarity, mutual understanding and repeated collaborations (Nooteboom, Noorderhaven, 1997).

Granovetter (1973) underlined the importance of weak ties in reaching other firms and building networks with companies having different and/or new ideas and perspectives. Weak ties mean more distant contacts that provide access to new flows of information and make it possible to build new relationships without been constrained by formal rules, group loyalties or expectations (Tracey, Clark, 2003).

If it is useful for innovative companies to rely on a combination of strong and weak ties in a dynamic manner (Tracey, Clark, 2003), we argue that in the relationship between consultants and SMEs strong ties play the pivotal role. In other words, the success factor for building constructive and trustful relations between consultants and SMEs is given by the strength of strong ties that suggest a strong similarity between the two involved actors (Granovetter, 1973). A strong tie is the bridge that makes it possible to run the shortest and most effective path to enter inside an SME and get credibility and trust from its founder(s) and team. In the specific case of relationships between consultants and SMEs information does not need to be diffused on a large distance and to reach a large audience (cf weak ties); on the contrary, 
information has to circulate on a limited and internal basis because it relates to the sensible work of consultants impacting on the SME strategy. So, bridges have not to be crossed through many weak ties but to be kept controlled through selected strong ties built through a pathdependent process (Salvador et al., 2014) in order to overcome the distrust (Connelly et al., 2012) and fear of losing autonomy of SMEs.

According to Granovetter theory (1973), when we think about consultants and SMEs' founders, it is like thinking about the difference between friends (with whom one builds strong ties) and acquaintances (with whom one builds weak ties). The findings of our investigation revealed that the SMEs analysed are willing to trust consultants that have the same characteristics as the ones expected from a close friend, like trust, credibility and reliability. This aspect has been further confirmed by the consultants interviewed: they highlighted the need to build strong relationships and to adapt to the demands of SMEs; the specificities of SMEs lead to a specific behaviour and commitment (Morgan, Hunt, 1994) of the consultants.

Strong ties make it possible to breed local cohesion, to form a dense network, to create a sense of community in a concentrated particular small group. This is in essence what consultants have to keep in mind when they interact with SMEs.

Wright et al. (2012) argued that "standardization" plays an important part in the practice of consultancy, besides creativity, customization and novelty. Furthermore, Wright et al. (2012) affirmed that consultants may play not only a role of advisors and facilitators but also of "regulators or controllers". We argue that this situation may become a reality in SMEs only and only if strong ties and commitment at trust-based relationships are effectively previously built with external consultants.

\subsection{Limitations and future research}

Regarding limitations of the present paper and directions for further research, our study focuses only on a sample of companies located in the department of Drôme (France). A positive consequence of analysing a limited geographic coverage over a given period of time is that it makes it possible to undertake a very specific and deep case-study analysis. The trade-off is that one might question the external validity of this context and our findings. Anyway, this focus may be seen more as a strength than as a weakness. Given the difficulty of obtaining reliable data from SMEs, this is a first key step in trying to fill the gap regarding consulting services dedicated to this specific kind of firm. The analysis revealed interesting results that could be deepened in further research through quantitative analyses (linear regression models, probit, logit...) and/or additional interviews about the reasons why SMEs use or do not use consultancy services. Furthermore, Sturdy (1997) underlined the difficulties in exploring interactions among the actors involved in consultancy activities.

Our results suggest that an interesting research question could be to investigate in more depth the human relations established by the external advisors and the company founder. It could be interesting to test - through empirical analyses with data taken from balance sheets whether a real trust relationship built over a long time period results in a better growth and performance of the company. Furthermore, it could be interesting to analyse how external consultants are organising their internal changes in order to satisfy the ad hoc solutions actually required by SMEs, with a differentiation according to the sectors of activity.

\section{References}

ANTAL A. B. \& KREBSBACH-GNATH C. (2001), "Consultants as agents of organizational learning: the importance of marginality”, in Dierkes M., Child J., Nonaka I. eds, Handbook of Organizational Learning, Oxford, Oxford University Press.

BAAIJ M. G. (2014), An Introduction to Management Consultancy, London, Sage Publications.

BENGHOZI P.-J., SALVADOR E. (2014) "Are traditional industrial partnerships so strategic for research spinoff development? Some evidence from the Italian case”, Entrepreneurship \& Regional Development, vol. 26 (1-2): 4779. 
BENGHOZI P.-J. \& SALVADOR E. (2015), “Technological competition: a path towards commoditization or differentiation? Some evidence from a comparison of e-book readers", Systèmes d'Information et Management (SIM), Vol. 20, No. 3, pp. 97-135

BENNETT R. \& ROBSON P.J.A. (1999), "The use of external business advice by SMEs in Britain", Entrepreneurship \& Regional Development, Vol. 11, pp. 155-180

BERRY A.J., SWEETING R. \& GOTO, J. (2006), "The effect of business advisers on the performance of SMEs", Journal of Small Business and Enterprise Development, Vol. 13, No. 1, pp. 33-47

BJERREGAARD T. (2010), "Industry and academia in convergence: micro-institutional dimensions of R\&D collaboration", Technovation, vol. 30, pp. 100-108.

BOTER H., LUNDSTRÖM A. (2005), "SME perspectives on business support services", Journal of Small Business and Enterprise Development, Vol. 12, No. 2, pp. 244-258

BRUNEEL J., D'ESTE P., SALTER A. (2010), "Investigating the factors that diminish the barriers to universityindustry collaboration", Research Policy, vol. 39, pp. 858-868.

CAREY P. (2015), "External accountants' business advice and SME performance”, Pacific Accounting Review, vol. 27, n. 2, pp. 166-188.

CAREY P., TANEWSKI G. (2016), "The provision of business advice to SMEs by external accountants", Managerial Auditing Journal, vol. 31, n. 3, pp. 290-313.

CHABAUD D., SAMMUT S. (2016), «Le dirigeant au cœur des dynamiques entrepreneuriales des PME », Editorial, Revue de l'Entrepreneuriat, vol. 15, n. 1, pp. 7-13.

CHEN, M.-H., WANG, M.-C. (2008), "Social networks and a new venture's innovative capability: the role of trust within entrepreneurial teams", $R \& D$ Management, Vol. 38 No. 3, pp. 253-264.

CHIU T., FANG D., CHEN J., WANG Y. \& JERIS C. (2001), “A robust and scalable clustering algorithm for mixed type attributes in large database environment", Proceedings of the 7th ACM (Association for Computing Machinery) SIGKDD international conference on knowledge discovery and data mining, New York, NY, USA, pp. 263-268

CHRISTENSEN C. M., WANG D., van BEVER D. (2013), "Consulting on the cusp of disruption”, Harvard Business Review, October, pp. 106-114.

COLEMAN, J.S. (1988), "Social capital in the creation of human capital”, American Journal of Sociology, Vol. 94 (Supplement), pp. 95-120.

CONNELLY B. L., MILLER T., DEVERS C. E. (2012), "Under a cloud of suspicion: trust, distrust, and their interactive effect in interorganizational contracting", Strategic Management Journal, vol. 33, pp. 820-833.

CURRAN J. (2000), "What is small business policy in the UK for? Evaluation and assessing small business policies", International Small Business Journal, Vol. 18, No. 3, pp. 36-50

DALY M., MCCANN A. (1992), “How many small firms?”, Employment Gazette, Vol. 100, No. 2, pp. 47-51

DAMANPOUR, F., ARAVIND, D. (2012), "Managerial Innovation: Conceptions, Processes, and Antecedents", Management \& Organization Review, vol. 8, n. 2, p.423-454.

DAMANPOUR, F., SCHNEIDER, M. (2009), "Characteristics of Innovation and Innovation Adoption in Public Organizations: Assessing the Role of Managers", Journal of Public Administration Research \& Theory, vol. 19, n. 3, p.495-522.

DANDRIDGE T.C. (1979), "Children are not 'little grown-ups': small business needs its own organizational theory", Journal of Small Business Management, Vol. 17, No. 2, pp. 53-57

DEGEORGE J.-M. (2015), "Editorial. Méthodologie qualitative et processus : deux frontières de la recherche en entrepreneuriat », Revue de l'Entrepreneuriat, vol. 14, n. 1, pp. 7-13.

DYER J. H., CHU W. (2003), "The Role of Trustworthiness in Reducing Transaction Costs and Improving Performance: Empirical Evidence from the United States, Japan, and Korea”, Organization Science, vol. 14, n. 1, pp. 57-68.

EUROPEAN COMMISSION (2014), Annual Report on European SMEs 2013/2014-A partial and fragile recovery, pp. 1-124

FINCHAM R., CLARK T. (2002), "Introduction: the emergence of critical perspectives on consulting", in Clark T., Fincham R., eds, Critical Consulting, Oxford, Blackwell, pp. 1-18.

FINCHAM R., CLARK T. (2003), "Preface. Management consultancy: issues, perspectives, and agendas", International Studies of Management and Organization, vol. 32, n. 4, pp. 3-18.

FINCHAM R., CLARK T., HANDLEY K., STURDY A. (2008), "Configuring expert knowledge: the consultant as sector specialist”, Journal of Organizational Behavior, vol. 29, pp. 1145-1160.

FLOYD D., MCMANUS J. (2005), "The role of SMEs in improving the competitive position of the European Union”, European Business Review, Vol. 17, No. 2, pp. 144-150 
GERVAIS M. (1978), "Pour une théorie de l'organisation-PME”, Revue Française de Gestion, No. 15, pp. 37-48

GIBB A. (2000), "SME policy, academic research and the growth of ignorance, mythical concepts, myths, assumptions, rituals and confusions", International Small Business Journal, Vol. 18, No. 3, pp. 13-34

GILBERT B., MCDOUGALL P., AUDRETSCH D. (2006), "New venture growth: a review and extension”, Journal of Management, Vol. 32, No. 6, pp. 926-950

GIOIA, D.A., CORLEY, K.G., HAMILTON, A.L. (2013), "Seeking qualitative rigor in inductive research: Notes on the Gioia methodology", Organizational research methods, vol. 16, n. 1, pp. 15-31.

GLODEK P., STAWASZ E., LOBACZ K., NIEDZIELSKI P. (2016), "Development of competitive advantage of small innovative firm - the role of use and utilisation of business advice“, Business \& Management Review, vol. 8, n. 3, pp. 67-78.

GORB P., DOWELL P. \& WILSON P. (1981), Small Business Perspectives, Armstrong, London

GRANOVETTER M. S. (1973), “The Strength of Weak Ties”, American Journal of Sociology, vol. 78, n. 6, pp. 1360-1380.

GULATI R. (1995), "Does familiarity breed trust? The implications of repeated ties for contractual choice in alliances", Academy of Management Journal, vol. 38, n. 1, pp. 85-112.

HAMEL, G. (2006), "The Why, What, and How of Management Innovation", Harvard Business Review, vol. 84, n², pp. 72-84.

HANNAN M.T. (2005), "Ecologies of organizations: diversity and identity", Journal of Economic Perspectives, Vol. 19, No. 1, pp 51-70

HANNAN M.T., FREEMAN J. (1977), “The population ecology of organizations”, American Journal of Sociology, Vol. 82, No. 5, pp 929-964

HANNAN M.T., FREEMAN J. (1984), "Structural inertia and organizational change", American Sociological Review, Vol. 49, No. 2, pp 149-164

HANNAN M.T., FREEMAN J. (1989), Organizational Ecology, Harvard University Press, Cambridge, MA

HANNAN M.T., POLOS L., CARROLL G.R. (2004), "The evolution of inertia", Industrial and Corporate Change, Vol. 13, No. 1, pp 213-242

HENISZ W.J., LEVITT R.E. (2011) "Regulative, normative, and cognitive institutional supports for relational contracting in infrastructure projects", Collaboratory for Research on Global Projects (CRGP), Working Paper 55.2

HICKS J., NAIR P., WILDEROM C. P. M. (2009), "What if we shifted the basis of consulting from knowledge to knowing?", Management Learning, vol. 40, n. 3, pp. 289-310.

HLADY RISPAL M., JOUISON-LAFFITTE E. (2015), «La contribution des méthodes qualitatives au développement du champ de l'entrepreneuriat », Revue de l'Entrepreneuriat, vol. 14, n. 1, pp. 15-40.

INSEE (2013), Les entreprises en France, Institut National de la Statistique et des Etudes Economiques, Paris, France, pp. 1-196.

JACK S., DRAKOPOULOU, DODD S., ANDERSON A.R. (2008), "Change and the development of entrepreneurial networks over time: a processual perspective”, Entrepreneurship \& Regional Development, Vol. 20, No. 2, pp. 125159

JAY L., SCHAPER M. (2003), "Which advisers do micro-firms use? Some Australian evidence", Journal of Small Business and Enterprise Development, Vol. 10, No. 2, pp. 136-143

JULIEN P.-A. (under the direction of) (1994), Les PME: bilan et perspectives, Paris, Economica et Presses Inter Universitaires

JULIEN P.-A, MANCHESNAY M. (1988), La petite entreprise, Paris, Vuibert (Gestion)

KALIKA M. (1988), Structure d'entreprises : réalités, déterminants, performances, Paris, Economica (Gestion)

KENT P. (1994), "Management advisory services and the financial performance of clients", International Small Business Journal, Vol. 12, No. 4, pp. 45-58

KIM J.I, YOU Y.Y., KIM J.R. (2015), "An empirical study as to an effect on policy satisfaction of small and medium-sized firms which got consulting”, Indian Journal of Science and Technology, Vol. 8, No. 7, pp. 701-710

KLINE P. (1994), An Easy Guide to Factor Analysis, London \& New York, Routledge

LAUDER D., BOOCOCK G., PRESLEY J. (1994), "The system of support for SMEs in the UK and Germany", European Business Review, Vol. 94, No. 1, pp. 9-16

LIGHTFOOD G. (1998), Financial management and small firm owner managers, PhDthesis, Kingston upon Thames

LORY M., McCALMAN J. (2002), “Management consultancies as brands: can David learn from Goliath?”, Brand Management, vol. 9, n. 6, pp. 412-429. 
MARCHESNAY M. (2003), "La petite entreprise: sortir de l'ignorance", Revue Française de Gestion, Vol. 3, No. 144, pp. $107-118$

McKENNA C. (2006), The world's newest profession, Cambridge, Cambridge University Press.

MIHAI D. (2009), "Quantitative study regarding the SME's organizational behaviour as regards management consultancy services", Bulletin of the Transilvania University of Brasov, Series V: Economic Sciences, Vol. 2, No. 51, pp. 43-46

MOL, M. J. ET BIRKINSHAW, J. (2014), "The Role of External Involvement in the Creation of Management Innovations", Organization Studies, vol. 35, n9, p.1287-1312.

MOLE K. (2002), "Business advisers' impact on SMEs: an agency theory approach”, International Small Business Journal, Vol. 20, No. 2, pp. 139-162

MOOI E. \& SARSTEDT S. (2011), “Cluster analysis”, A Concise Guide to Market Research, Chap. 9, pp. 237-284

MORGAN R. M., HUNT S. D. (1994), “The Commitment-Trust Theory of Relationship Marketing”, Journal of Marketing, vol. 58, July, pp. 20-38.

MOSLEY D. C. (1970), "Professional ethics and competence in management consulting", California Management Review, vol. XII, n. 3, pp. 44-48.

MUGHAN T., LLOYD-REASON L., ZIMMERMAN C. (2004), "Management consulting and international business support for SMEs: need and obstacles", Education + Training, Vol. 46, No. 8/9, pp. 424-432

NICOLESCU O. (2009), "Main features of SMEs organisation system", Review of International Comparative Management, Vol. 10, No. 3, pp. 405-414

NIEDERGASSEL B., LEKER J. (2011), "Different dimensions of knowledge in cooperative R\&D projects of university scientists", Technovation, vol. 31, pp. 142-150.

NOOTEBOOM B., BERGER H., NOORDERHAVEN N. G. (1997), "Effects of trust and governance on relational risk", Academy of Management Journal, vol. 40, n. 2, pp. 308-338.

NORTH D., SMALLBONE D., VICKERS I. (2001), "Public sector support for innovating SMEs", Small Business Economics, Vol. 16, No. 4, pp. 303-317.

NORUSIS M.J. (2009), “Cluster analysis”, SPSS 16.00 Statistical Procedures Companion. Prentice-Hall, Englewood Cliffs, NJ

O'REGAN N., GHOBADIAN A. (2004), "Testing the homogeneity of SMEs: the impact of size on managerial and organisational processes", European Business Review, Vol. 16, No. 1, pp. 64-77

O’SHEA J., MADIGAN C. (1998), Dangerous company, New York, NY Penguin.

PENROSE E.T. (1959), The Theory of the Growth of the Firm, Oxford: Basil Blackwell

PULLEN A., WEERD-NEDERHOF P., GROEN A., FISSCHER O. (2008), "Configurations of external SME characteristics to explain differences in innovation performance", 16th Annual High Technology Small Firms (HTSF) Conference, 21-23 May 2008, Enschede, The Netherlands

PURANAM P., VANNESTE B. S. (2009), "Trust and governance: untangling a tangled web", Academy of Management Review, vol. 34, n. 1, pp. 11-31.

RAMSDEN M., BENNETT R.J., (2005), “The benefits of external support to SMEs: 'hard' versus 'soft' outcomes and satisfaction levels", Journal of Small Business and Enterprise Development, Vol. 12, No. 2, pp. 227-243

REVILLA E., SARKIS J., ACOSTA J. (2005), “Towards a knowledge management and learning taxonomy for research joint ventures”, Technovation, vol. 25, pp. 1307-1316.

RING P. S., VAN DE VEN A. H. (1992), "Structuring cooperative relationships between organizations", Strategic Management Journal, vol. 13, pp. 483-498.

RIVAL M., MAJOR R. (2018), "What lobbying ethics and what for? The case of French lobbying consulting firms", Journal of Business Ethics, vol. 150, pp. 99-116.

SALVADOR E., MARIOTTI I., CONICELlA F. (2013) "Science Park or Innovation Cluster? Similarities and differences in physical and virtual firms' agglomeration phenomena", International Journal of Entrepreneurial Behaviour \& Research, vol. 19, n. 6, pp. 656-674.

SALVADOR E., PINOT DE VILLECHENON F., LOPEZ-RIZZO H. (2014), "European SMEs and the Brazilian market: the key role of social networks", European Business Review, vol. 26, No. 4, pp. 368-388

SCOTT R.W. (2008), Institutions and Organizations: Ideas and Interests, Sage Publications, Thousand Oaks, CA

SHERWOOD A. L., COVIN J. G. (2008), "Knowledge acquisition in university-industry alliances: an empirical investigation from a learning theory perspective", The Journal of Product, Innovation, Management, vol. 25, pp. 162179. 
SORIANO D., ROIG S., SANCHIS J.R, TORCAL R. (2002), "The role of consultants in SMEs - The use of services by Spanish industry”, International Small Business Journal, Vol. 20, No. 1, pp. 95-103

SRINIVASAN R. (2014), "The management consulting industry: growth of consulting services in India - Panel discussion", IIMB Management Review, Vol. 26, No. 4, pp. 257-270

ST-PIERRE J., CADIEUX L. (2011), «La conception de la performance : quels liens avec le profil entrepreneurial des propriétaires dirigeants de PME ? », Revue de l'Entrepreneuriat, vol. 10, n. 1, pp. 33-52.

STURDY A., CLARK T., FINCHAM R., HANDLEY K. (2009), "Between innovation and legitimation - boundaries and knowledge flow in management consultancy", Organization, vol. 16, n. 5, pp. 627-653.

STURDY A. (1997), “The consultancy process - an insecure business?”, Journal of Management Studies, vol. 34, n. 3, pp. 389-413.

STURDY A. (2009), "Popular critiques of consultancy and a politics of management learning", Management Learning, vol. 40, n. 4, pp. 457-463.

STURDY A. (2011), “Consultancy's consequences? A critical assessment of management consultancy's impact on management", British Journal of Management, vol. 22, pp. 517-530.

STURDY A., WYLIE N., WRIGHT C. (2013), "Management consultancy and organizational uncertainty", International Studies of Management and Organization, vol. 43, n. 3, pp. 58-73.

THRIFT N. (2005), Knowing capitalism, London, Sage.

TORRES O. (1997), "Pour une approche contingente de la spécificité de la PME", Revue Internationale PME, Économie et Gestion de la Petite et Moyenne Entreprise, Vol. 10, No. 2, pp. 9-43

TORRÈS O., PLANE J.M. (1998), “Le recours au conseil est-il un processus dénaturant pour la PME ?”, 4e Congrès International Francophone en Entrepreneuriat et PME (CIFEPME), 22-24 Octobre 1998, Nancy-Mets, France

TRACEY P., CLARK G. L. (2003), "Alliances, networks and competitive strategy: rethinking clusters of innovation”, Growth and Change, vol. 34, n. 1, pp. 1-16.

VAN GELDEREN M., JANSON P. (2006), "Autonomy as a start-up motive", Journal of Small Business and Enterprise Development, Vol. 13, No. 1, pp. 23-32

VEDEL B., GABARRET I. (2014), "The role of trust as mediator between contract, information and knowledge within business incubators", International Journal of Entrepreneurship and Small Business, vol. 23, n. 4, pp. 509527.

VILJAMAA A. (2011), "Exploring small manufacturing firms' process of accessing external expertise", International Small Business Journal, Vol. 29, No. 5, pp. 472-488

WELSH J.A., WHITE J.F. (1981), “A small business is not a little big business”, Harvard Business Review, Vol. 59, No. 4 , pp. $18-32$

WRIGHT C., STURDY A., WYLIE N. (2012), "Management innovation through standardization: consultants as standardizers of organizational practice", Research Policy, vol. 41, pp. 652-662.

YIN, R. (2003), Case study research: Design and methods, 3rd ed. Sage Publications.

XIN K.R., PEARCE J.L. (1996) “Guanxi: connections as substitutes for formal institutional support”, Academy of Management Journal, Vol. 39, No. 6, pp. 1641-1658

Annex: Figure 4: SPSS output of the two-step cluster analysis

Model Summary

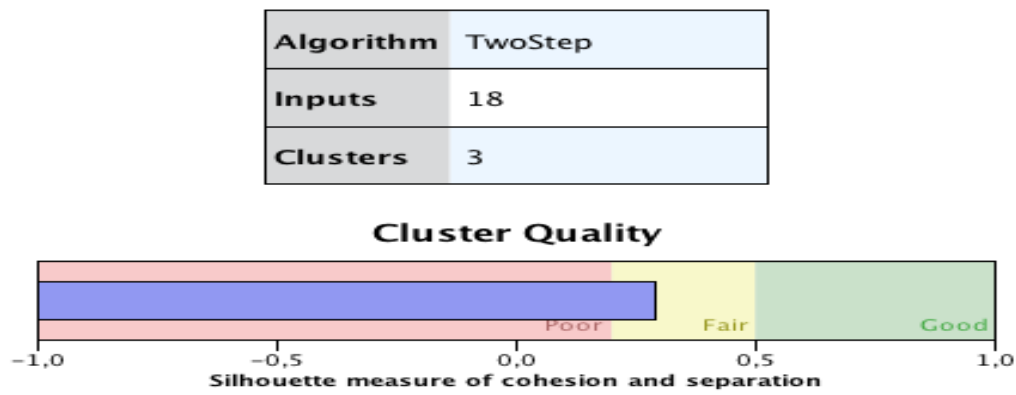


Table 1: Anova

\begin{tabular}{|c|c|c|c|c|c|c|}
\hline \multicolumn{7}{|l|}{ ANOVA } \\
\hline & & Sum of Squares & df & Mean Square & $\mathrm{F}$ & Sig. \\
\hline \multirow[t]{3}{*}{ BINCom_Public } & Between Groups & 3,759 & 2 & 1,880 & 11,513 &, 000 \\
\hline & Within Groups & 5,714 & 35 & ,163 & & \\
\hline & Total & 9,474 & 37 & & & \\
\hline \multirow[t]{3}{*}{ BINCom_DomainSpecial } & Between Groups & ,969 & 2 & ,485 & 2,154 & ,131 \\
\hline & Within Groups & 7,873 & 35 & ,225 & & \\
\hline & Total & 8,842 & 37 & & & \\
\hline \multirow[t]{3}{*}{ BINCom_SectorSpecial } & Between Groups &, 766 & 2 & ,383 & 1,801 &, 180 \\
\hline & Within Groups & 7,444 & 35 & ,213 & & \\
\hline & Total & 8,211 & 37 & & & \\
\hline \multirow[t]{3}{*}{ BINCom_IndependentLT } & Between Groups & 3,150 & 2 & 1,575 & 9,299 & ,001 \\
\hline & Within Groups & 5,929 & 35 &, 169 & & \\
\hline & Total & 9,079 & 37 & & & \\
\hline \multirow[t]{3}{*}{ BINMana_Public } & Between Groups & 7,696 & 2 & 3,848 & 75,757 & 000 \\
\hline & Within Groups & 1,778 & 35 & ,051 & & \\
\hline & Total & 9,474 & 37 & & & \\
\hline \multirow{3}{*}{ BINMana_DomainSpecial } & Between Groups &, 014 & 2 & ,007 & ,039 & ,961 \\
\hline & Within Groups & 6,302 & 35 &, 180 & & \\
\hline & Total & 6,316 & 37 & & & \\
\hline \multirow[t]{3}{*}{ BINMana_SectorSpecial } & Between Groups & 6,784 & 2 & 3,392 & 45,465 &, 000 \\
\hline & Within Groups & 2,611 & 35 &, 075 & & \\
\hline & Total & 9,395 & 37 & & & \\
\hline \multirow[t]{3}{*}{ BINMana_IndependentLT } & Between Groups & 4,602 & 2 & 2,301 & 25,053 &, 000 \\
\hline & Within Groups & 3,214 & 35 & ,092 & & \\
\hline & Total & 7,816 & 37 & & & \\
\hline \multirow[t]{3}{*}{ BINReason_NoFinancial } & Between Groups &, 227 & 2 &, 114 & ,478 & 624 \\
\hline & Within Groups & 8,325 & 35 & ,238 & & \\
\hline & Total & 8,553 & 37 & & & \\
\hline \multirow[t]{3}{*}{ BINReason_NoTime } & Between Groups &, 022 & 2 & ,011 & ,041 & ,960 \\
\hline & Within Groups & 9,373 & 35 & ,268 & & \\
\hline & Total & 9,395 & 37 & & & \\
\hline \multirow[t]{3}{*}{ BINReason_InternalResources } & Between Groups & 1,032 & 2 & ,516 & 2,132 & ,134 \\
\hline & Within Groups & 8,468 & 35 & 242 & & \\
\hline & Total & 9,500 & 37 & & & \\
\hline \multirow[t]{3}{*}{ BINReason_Distrust } & Between Groups & ,909 & 2 & ,454 & 3,313 & ,048 \\
\hline & Within Groups & 4,802 & 35 &, 137 & & \\
\hline & Total & 5,711 & 37 & & & \\
\hline \multirow[t]{3}{*}{ BINFactor_Price } & Between Groups & 1,263 & 2 & ,632 & 2,763 & 077 \\
\hline & Within Groups & 8,000 & 35 & ,229 & & \\
\hline & Total & 9,263 & 37 & & & \\
\hline \multirow[t]{3}{*}{ BINFactor_TimeInvolvement } & Between Groups & 3,624 & 2 & 1,812 & 12,868 &, 000 \\
\hline & Within Groups & 4,929 & 35 &, 141 & & \\
\hline & Total & 8,553 & 37 & & & \\
\hline \multirow[t]{3}{*}{ BINFactor_Relationship } & Between Groups & 1,846 & 2 & ,923 & 10,077 &, 000 \\
\hline & Within Groups & 3,206 & 35 & ,092 & & \\
\hline & Total & 5,053 & 37 & & & \\
\hline \multirow[t]{3}{*}{ BINFactor_AcademicLevel } & Between Groups &, 242 & 2 &, 121 & ,775 & ,468 \\
\hline & Within Groups & 5,468 & 35 & ,156 & & \\
\hline & Total & 5,711 & 37 & & & \\
\hline \multirow[t]{3}{*}{ BINFactor_UnderstandingTime } & Between Groups &, 543 & 2 & 272 & 1,392 & ,262 \\
\hline & Within Groups & 6,825 & 35 & ,195 & & \\
\hline & Total & 7,368 & 37 & & & \\
\hline Need_MeanValues & Between Groups & 2,771 & 2 & 1,385 & 2,478 & 099 \\
\hline & Within Groups & 19,572 & 35 &, 559 & & \\
\hline & Total & 22,343 & 37 & & & \\
\hline
\end{tabular}


Table 5: Clustering variables used for the cluster analysis

\begin{tabular}{|c|c|c|c|}
\hline & Variable name & Meaning & $\begin{array}{l}\text { Type of } \\
\text { variable }\end{array}$ \\
\hline 1 & Need_MeanValue & $\begin{array}{l}\text { The mean value of needs for each of the seven domains (finance \& } \\
\text { accounting, organisation \& management, marketing \& } \\
\text { communication, IT, strategy, business development, human } \\
\text { resources \& recruitment), (5-point Likert scale) }\end{array}$ & Continuous \\
\hline $2 \mathrm{a}$ & BINCom_DomainSpecial $^{1}$ & $\begin{array}{l}\text { A private entity specialised in business development is one of the } \\
\text { most preferred (1) or not }(0) \text { for support }\end{array}$ & Binary \\
\hline $2 b$ & BINCom_SectorSpecial & $\begin{array}{l}\text { A private entity specialised in the sector of activity is one of the } \\
\text { most preferred (1) or not ( } 0 \text { ) for support in business development }\end{array}$ & Binary \\
\hline $2 \mathrm{c}$ & BINCom_IndependentLT & $\begin{array}{l}\text { An independent consultant accompanying the SME on a long-term } \\
\text { basis is one of the most preferred (1) or not }(0) \text { for support in } \\
\text { business development. }\end{array}$ & Binary \\
\hline $2 d$ & BINCom_Public & $\begin{array}{l}\text { Support services directly offered by the CCI or other public entities } \\
\text { is one of the most preferred (1) or not ( } 0 \text { ) for support in business } \\
\text { development }\end{array}$ & Binary \\
\hline $2 \mathrm{e}$ & BINMana_DomainSpecial & $\begin{array}{l}\text { A private entity specialised in organisation \& management is one of } \\
\text { the most preferred (1) or not (0) for support }\end{array}$ & Binary \\
\hline $2 \mathrm{f}$ & BINMana_SectorSpecial & $\begin{array}{l}\text { A private entity specialised in the sector of activity is one of the } \\
\text { most preferred (1) or not }(0) \text { for organisation \& management }\end{array}$ & Binary \\
\hline $2 g$ & BINMana_IndependentLT & $\begin{array}{l}\text { An independent consultant accompanying the SME on a long-term } \\
\text { basis is one of the most preferred (1) or not }(0) \text { for support in } \\
\text { organisation \& management }\end{array}$ & Binary \\
\hline $2 \mathrm{~h}$ & BINMana_Public & $\begin{array}{l}\text { Support services directly offered by the CCI or other public entities } \\
\text { is one of the most preferred (1) or not }(0) \text { for support in } \\
\text { organisation \& management }\end{array}$ & Binary \\
\hline $3 a$ & BINReason_NoFinancial $^{2}$ & $\begin{array}{l}\text { The reason "the company does not have the financial resources to } \\
\text { contract (any/more) services" is true (1) or not (0) for not } \\
\text { contracting more support services }\end{array}$ & Binary \\
\hline $3 b$ & BINReason_NoTime & $\begin{array}{l}\text { The reason "I do not have time to request external support services" } \\
\text { is true ( } 1 \text { ) or not }(0) \text { for not contracting more support services }\end{array}$ & Binary \\
\hline $3 \mathrm{c}$ & BINReason_InternalResources & $\begin{array}{l}\text { The reason "I prefer using/want to use exclusively the internal } \\
\text { resources of the company" is true (1) or not ( } 0 \text { ) for not contracting } \\
\text { more support services }\end{array}$ & Binary \\
\hline $3 \mathrm{~d}$ & BINReason_Distrust & $\begin{array}{l}\text { The reason "I do not trust (anymore) and I am suspicious of } \\
\text { external consultants" is true (1) or not ( } 0 \text { ) for not contracting more } \\
\text { support services }\end{array}$ & Binary \\
\hline
\end{tabular}

\footnotetext{
${ }^{1}$ A question asked to rank by order of preference seven different kinds of sources of support or institutions. Thus, the respondents attributed to each of the seven suggestions a position from 1 to 7 (1 being the most preferred and 7 the least preferred). The question was asked twice (for support in business development and in organisation \& management). The descriptive analysis of the questionnaire resulted, for both the cases, in four most preferred institutions: an institution specialised in the sector of activity of the respondent, an institution specialised in the consultancy domain provided, an independent consultant providing services on a long-term basis, and a public entity. The difference in mean positions for these four institutions and the three others was significant; thus, we decided to keep only these four most preferred institutions and to transform them into binary variables.

${ }^{2}$ Another question asked the respondents at which level they agreed with potential reasons for not using additional support services. The reasons were suggested directly in the questionnaire and were based on the main findings of the literature review. The respondents had to evaluate their agreement on a 5-point Likert scale $(1=$ strongly disagree, $2=$ somewhat disagree, $3=$ neutral, $4=$ somewhat agree, and $5=$ strongly agree). We retained for the cluster analysis the following reasons: the limited financial resources, the lack of time of the manager, the distrust of consultants, and the willingness to use internal resources. Here again, the variables have been transformed into binary variables.
} 


\begin{tabular}{|l|l|l|c|}
\hline $4 \mathrm{a}$ & BINFactor_Price $^{1}$ & $\begin{array}{l}\text { The service's price is important when choosing a specific support } \\
\text { provider (1) or not (0) }\end{array}$ & Binary \\
\hline $4 \mathrm{~b}$ & BINFactor_TimeInvolvement & $\begin{array}{l}\text { The factor "the time that the consultant commits to spend to solve } \\
\text { my problem" is important when choosing a specific support } \\
\text { provider (1) or not (0) }\end{array}$ & Binary \\
\hline $4 \mathrm{c}$ & BINFactor_Relationship & $\begin{array}{l}\text { The factor "the relationship and the feeling that you have with the } \\
\text { consultant in terms of trust" is important when choosing a specific } \\
\text { support provider (1) or not (0) }\end{array}$ & Binary \\
\hline $4 \mathrm{~d}$ & BINFactor_AcademicLevel & $\begin{array}{l}\text { The academic level of the consultant is important when choosing a } \\
\text { specific support provider (1) or not (0) }\end{array}$ & Binary \\
\hline $4 \mathrm{e}$ & BINFactor_UnderstandingTime & $\begin{array}{l}\text { The time that the consultant spends understanding the problems of } \\
\text { the company, even before signing the contract, is important when } \\
\text { choosing a specific support provider (1) or not (0) }\end{array}$ & Binary \\
\hline
\end{tabular}

${ }^{1}$ The final part of the questionnaire concerned the potential factors influencing the respondent in his choice of a specific consultant. The question was based on a 5-point Likert scale from 1 for "not important at all" to 5 for "strongly important". The factors selected for the clustering analysis were related to the price, the time involvement, the relationship and trust, the understanding time, and the academic level of the consultant. Furthermore, the variables of the questionnaire have been transformed into binary clustering variables: 1 means that the importance is high, while 0 means that it is not at all important. 